\title{
SENSE AND NONSENSE ABOUT SECURITIES LITIGATION
}

\author{
Richard A. Booth
}

ABSTRACT

In We Have a Consensus on Fraud on the Market - And It's Wrong, James Spindler attempted to defend securities fraud class actions ("SFCAs") and the fraud-on-the-market ("FOTM") doctrine by purporting to refute two arguments that have been cited by numerous scholars: (1) the circularity (feedback) critique and (2) the diversification critique. In essence, Spindler's gist is that SFCAs are both workable and necessary. But, in the end, Spindler exposes weaknesses in the usual arguments against SFCAs that point the way to still stronger arguments against SFCAs.

Regarding circularity, Spindler argues that SFCAs are workable because it is possible, even with circularity, for investors to be compensated in full, even though compensation is funded by a reduction in the aggregate value of the defendant company, and thus the wealth of its stockholders (including those who are compensated). But he fails to recognize that because feedback magnifies buyer claims, it induces investors to spend that much more on precaution and increases already excessive deterrence. Moreover, it effects a transfer of wealth from diversified investors to stockpicking investors even though the law should encourage investors to diversify.

Regarding diversification, Spindler argues that SFCAs are necessary because one cannot diversify away fraud. But as shown here, the loss from securities fraud is a mixture of diversifiable losses that someone will suffer one way or the other (when the truth comes out) and undiversifiable losses that derive from the cover-up of bad news. Bad things happen to good companies. Sales decline. Risks increase. But such losses can be diversified away because unexpectedly good things happen to other companies. In contrast, if an ordinary loss is exacerbated by a cover-up leading to a loss of investor trust (and an increased cost of capital) or cash outflows (from litigation expenses or fines), such additional losses cannot be offset by unexpected gains. There is no potential for gain from the absence of fraud.

The only losses that really matter are the losses that cannot be diversified away. But these are losses suffered by the corporation that should 
give rise to a derivative action. Moreover, it turns out that derivative actions are perfectly tailored to compensate investors and to provide perfectly calibrated deterrence without the collateral damage caused by feedback.

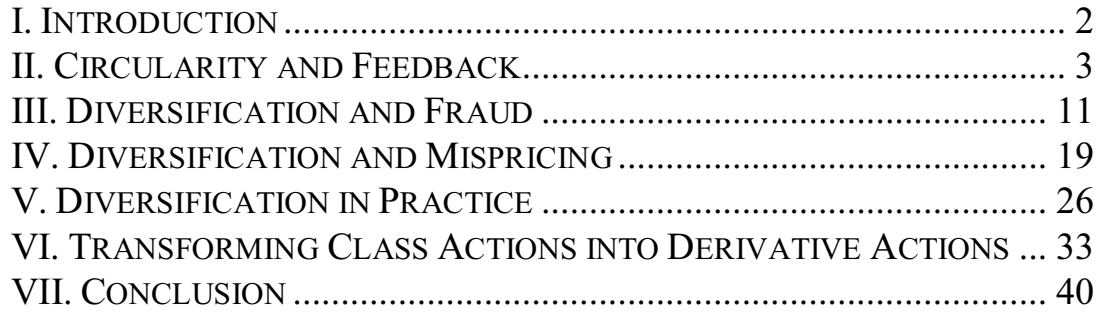

\section{INTRODUCTION}

In We Have a Consensus on Fraud on the Market - And It's Wrong, James Spindler argues that the near universal disdain of legal scholars for securities fraud class actions ("SFCAs") is based on two mistaken ideas: (1) that compensation for securities fraud is impossible because recovery against the issuer means that defrauded buyers effectively pay themselves (the circularity critique) and (2) that most investors are diversified and thus suffer no real harm from securities fraud since buy-side losses wash out from sellside gains on average and over time (the diversification critique). ${ }^{1}$

Spindler purports to refute both of these arguments. But, the arguments he refutes are not exactly the arguments against SFCAs. In other words, Spindler resorts to the time-honored technique of misstating the opposing argument in order to attack it. I do not mean to suggest that the arguments addressed and refuted by Spindler have never been made. Rather, these arguments have been supplanted by a more refined critique of SFCAs that is far more compelling.

Nevertheless, Spindler's piece is a valuable contribution to the extensive body of legal scholarship focusing on securities litigation if only because it recounts the evolution of scholarly thinking about SFCAs. But, his biggest contribution in this piece is in showing how the arguments against SFCAs have been misunderstood. Thus, Spindler shows that the arguments against SFCAs could be much clearer.

1. James C. Spindler, We Have a Consensus on Fraud on the Market - And It's Wrong, 7 HARV. Bus. L. REv. 67, 69-91 (2017). Technically speaking, Spindler confuses the fraud on the market ("FOTM") doctrine (a presumption of reliance) with SFCAs (a procedure and a remedy). $I d$. at 73-77. 


\section{CIRCULARITY AND FEEDBACK}

Spindler summarizes his argument regarding circularity and feedback as follows:

The circularity critique fails mathematically: as shown herein with an economic model, penalties on the firm effectively come out of the pockets of non-plaintiff shareholders, and actually do compensate plaintiffs. To the extent that the firm's shares have been turned over during the effective period of the fraud, it is true that the plaintiff class seeks recovery from a firm that they, in part, own. But just as a non-pro-rata dividend transfers wealth, on net, to its recipients, so, too, does the fraud on the market remedy. What is more remarkable is that, under certain conditions, compensation is full and complete. This is so because of a feedback effect between damages and liability: prospective liability decreases stock price, which increases prospective liability, which decreases stock price, and so on. As illustrated mathematically in Part III, infra, the interaction between turnover, stock price, and damages works to fully compensate defrauded purchasers. $^{2}$

Spindler is correct that circularity does not preclude compensation. In theory, buyers may be made whole, even though (as holders) they effectively pay themselves a portion of any recovery, because most of the recovery usually comes from non-buyer holders. ${ }^{3}$ But no one really argues that

2. Spindler, supra note 1 , at 70 .

3. Note that a securities fraud claim may arise from the cover-up of either bad news or good news. In the former case, the plaintiff class comprises those who bought during the fraud period, while in the latter case the plaintiff class comprises those who sold during the fraud period. Although there are notable examples of good news cases (with seller classes), the overwhelming majority of SFCAs involve the cover up of bad news (with buyer classes). My own study of one random year revealed that 104 out of 106 cases filed involved the coverup of bad news. Thus, only two cases involved the cover-up of good news. Accordingly, the discussion here assumes the context of a bad news case with a buyer class.

It is not surprising that companies might be more reluctant to disclose bad news. Spindler would likely say that issuers always want to inflate the price of their stock (so they can sell for too much if they should want to sell) but that the cover-up of good news would serve only non-stockholder buyers. See James C. Spindler, Optimal Deterrence When Shareholders Desire Fraud 3 (November 17, 2017) (unpublished manuscript), available at https://ssrn.com/abstract=3121230 [https://perma.cc/EU6R-UW2P] (stating that corporate fraud arises from shareholder incentives). But SFCAs themselves may be the cause of this dramatic skew since they cause stock price to fall further than it otherwise would in bad news cases but to rise less than it otherwise would in good news cases. Thus, damages are magnified in bad news cases and muted in good news cases (as discussed immediately below).

Note also that the analysis herein assumes that the subject matter securities fraud is 
compensation is impossible. Rather, the argument is (or should be) that compensation is illusory for most investors because of the (hidden) losses they suffer as holders. On average and over time, most stockholders are net losers from SFCAs.

Moreover, as Spindler himself notes in the above quoted passage, the prospect of payout by the defendant company causes stock price to fall further than it would have in the absence of a class action remedy because of the feedback effect. ${ }^{4}$ As a result, SFCAs do more harm than good.

For example, suppose that Acme Blasting Cap, Inc. ("ABC") has been sued because it covered up information indicating that stock price should be $10 \%$ lower than it was before corrective disclosure - $\$ 9$ per share rather than $\$ 10$ per share. Assume further that the plaintiff class comprises $20 \%$ of outstanding shares. Because of the prospective payout to settle the class action, stock price falls further to $\$ 8.75$ per share (assuming full recovery). ${ }^{5}$

one in connection with trading in a common stock. It is quite possible for SFCAs to relate to trading in fixed income securities (debt and preferred stock), but common stock is by far the most common subject of SFCAs. Moreover, many of the issues discussed here do not arise in the same way in connection with litigation relating to other securities. There is no real circularity or feedback when recovery by some common stockholders comes from other common stockholders. Diversification is a far less powerful factor in connection with fixed income securities that seldom increase in value because of firm-specific factors.

4. Curiously, Spindler seems to view feedback as a good thing, stating that "circularity and feedback operate together to preserve the net transfer to the plaintiff class at the level of actual damages." Spindler, supra note 1, at 93.

5. As far as I know, I was the first to identify and calculate the feedback effect. But Spindler provides a derivation for the formula that I found by iteration. Spindler, supra note 1, at 92-102. For the mathematically inclined, the formula for calculating the feedback effect in a bad news case is: total decrease $(\%)=$ expected loss $(\%) /(1-\%$ of damaged shares $)$. For example, if $50 \%$ of outstanding shares have a claim, then non-buyer holders lose double what their loss would be in the absence of SFCAs. See Richard A. Booth, The End of the Securities Fraud Class Action as We Know It, 4 BERKELEY Bus. L. J. 1, 24-27 (2007) (arguing that SFCAs should not be treated as class actions but rather as derivative actions).

To be clear, the price change happens immediately upon corrective disclosure. The market does not wait to see whether a SFCA will follow and how much it will cost to settle. To be sure, the market may change its mind over time as the situation plays out. But there is no way to know up front how much of the price decrease flows from a decrease in the fundamental value of the defendant company (lower return or higher business risk) and how much flows from feedback and other costs.

In a simple case where a single material fact is misrepresented for some period and then completely disclosed, the number of damaged shares is equal to the number of additional shares held by different shareholders as of the date of corrective disclosure relative to the number held at the beginning of the fraud period. This number might be called unique turnover and is equal to total volume net of in-and-out trading. See generally Robert A. Alessi, The Emerging Judicial Hostility to the Typical Damages Model Employed by Plaintiffs in Securities Class Action Lawsuits, 56 BuS. LAw 483, 483 (2001) (remarking on the judiciary's growing intolerance for the untested, speculative nature of a typical plaintiff's 
In such a case, an investor who owns 1000 shares and who bought 100 of those shares during the fraud period will recover $\$ 125$ on the 100 shares bought, but will lose \$225 more on the 900 shares held from before the fraud period than would have been lost in the absence of a class action remedy. Specifically, stock price falls by an extra $\$ 0.25$. So, a stockholder who holds 900 shares from before the fraud loses $\$ 0.25 * 900=\$ 225$. $^{6}$ Moreover, the recovery of $\$ 125$ does not reflect any subtraction from the recovery for attorney fees. If plaintiff attorneys receive $20 \%$ of the award, the stockholder in the example would recover just $\$ 100 .^{7}$

damages model in security related class actions).

6. See Richard A. Booth, Index Funds and Securities Fraud Litigation, 64 S.C. L. REV. 265, 287 (2012) (discussing how index funds almost always lose more than they gain). It is surprising that sophisticated investors seem not to grasp the problem. For example, the general counsel of a major (index) fund manager once told me that it was remarkable how much money they took in from class action settlements.

7. These calculations assume that the remedy works as intended and that the market correctly assesses the effects of litigation. But the argument here does not depend on full compensation of investors, nor does it depend on market efficiency. In the real world, buyers never recover $100 \%$ of their losses. So, defendant companies never pay full freight. But, the feedback effect obtains to the extent of any payout by the defendant company. Moreover, bargaining happens in the shadow of the law. So, the measure of damages dictates where negotiation starts.

Spindler notes that insurance may dampen the feedback effect. Spindler, supra note 1 , at 100. This is obviously correct if SFCAs tend to settle for less than the full loss suffered by buyers (say) because the class accepts whatever amount is available under a directors' and officers' liability ("D\&O") insurance policy. It is also correct if insurers raise rates generally rather than according to insured-specific claim experience (as appears to be common practice). But if insurers do raise rates company-by-company in order to recoup payouts from the companies whose claims have been covered, the effect will be to enhance feedback, because the increased expense of insurance (including the mark-up charged by the insurer) will reduce the returns generated by the insured company going forward and thus reduce stock price by the present value thereof. Presumably, the insured company would be better off borrowing to finance any settlement (unless its cost of new debt exceeds the markup charged by the insurer). Even if rate increases are spread over many public companies (if insurers decline to charge company-specific rates in light of claims experience), the cost of insurance operates as a tax on public companies and investor returns (presumably exceeding the aggregate payout to investors to the extent of insurer markup as noted above).

In addition, the market may overreact to bad news. The tendency of stock price to overreact to bad news - giving rise to so-called crash damages - has been noted by scholars and Congress itself in the passage of the Private Securities Litigation Reform Act ("PSLRA") of 1995. See Janet Cooper Alexander, The Value of Bad News in Securities Class Actions, 41 UCLA L. REV. 1421, 1468 (1994) (concluding that the calculation of class damages under current law is analytically flawed because it sweeps in elements of the market's reaction to bad news that are not within the legal definition of damages); Bradford Cornell \& James C. Rutten, Market Efficiency, Crashes, and Securities Litigation, 81 Tul. L. Rev. 443, 443 (2006) (arguing that a failure to understand implications of the efficient market hypothesis introduces a significant plaintiff bias in securities class action litigation); Werner F.M. 
Although one might object to the assumption in the example that an investor who owns $900 \mathrm{ABC}$ shares buys an additional 100 shares of the same stock, the fact is that such a scenario is quite common. It is standard practice for index investors to buy or sell a few shares of portfolio stocks as part of periodic rebalancing. Indeed, turnover for the S\&P 500 is about $4.5 \%$ annually. ${ }^{8}$ It follows that index investors always lose from SFCAs, and index investors constitute more than $45 \%$ of the market (by value). ${ }^{9}$

To be clear, it is not the argument here that one can diversify away the effects of fraud. Rather, the argument is that diversified investors pay more than they recover with SFCAs as the remedy for fraud. For them, the cure is worse than the disease.

While the foregoing argument is compelling for a diversified stockholder, a stock-picking investor will lose whenever she is a holder rather than a buyer. Thus, the question remains whether the benefit is worth the cost even for undiversified investors. ${ }^{10}$ There is no doubt that an aggrieved buyer would like this remedy from an ex post perspective. But the question is whether investors want this remedy from an ex ante perspective. In other words, as an investor who does not know if I will be a buyer or a holder in any given case, would I prefer a system with or without SFCAs if I understand that on average and over time I will pay more than I get back?

Admittedly, the same is true with any form of insurance. But people

DeBondt \& Richard Thaler, Does the Stock Market Overreact?, 40 J. FIN. 793, 804 (1985) (explaining that the stock market may overreact to unexpected and dramatic news events); Werner F.M. DeBondt \& Richard H. Thaler, Further Evidence on Investor Overreaction and Stock Market Seasonality, 42 J. Fin. 557, 579 (1987) (finding systematic price reversals for stocks that experienced extreme long-term gains or losses); Baruch Lev \& Meiring de Villiers, Stock Price Crashes and 10b-5 Damages: A Legal, Economic, and Policy Analysis, 47 Stan. L. REv. 7, 7 (1994) (discussing how a "crash price" is an unreliable and economically unsound measure of damages). See also Conference Report on Private Securities Litigation Reform Act, H.R. Rep. No. 104-369, at CCH 9304 (1995) (designed to limit frivolous securities lawsuits). Remarkably, none of these sources note that feedback may contribute to crash damages.

8. S\&P Capitalization Weighted Turnover, S\&P Dow JONES INDICES, https://us.spindic es.com/documents/additional-material/turnover.xlsx?force_download=true [https://perma.cc/9QXA-VRJ5] (last visited Nov. 30, 2017).

9. Annual Survey of Assets as of Dec. 31, 2016, S\&P Dow Jones INDICES, https://www .spindices.com/documents/additional-material/spdji-asset-survey-2016.pdf. As discussed further below, the conflict of interests between index investors and stock pickers is legally relevant in that it should preclude any class certification.

10. One's preference may also depend on how often one trades. An active stock-picking trader who holds one and only one stock for a few days or weeks at a time - who sells one stock to buy another - is unlikely to suffer any loss as a holder except if the class period is very short. For the record, average turnover among actively managed mutual funds is about $50 \%$ per year, and the average class period is about 300 days. 
still buy insurance. On the other hand, most people buy insurance only against significant risks of loss that might be difficult to absorb in the ordinary course. Think life insurance or fire insurance. Similarly, whether one would favor SFCAs depends somewhat on whether one is a stockpicking investor who may have a lot of eggs in one basket or rather a diversified investor. For a diversified investor, SFCAs are equivalent to buying an extended warranty on a toaster. ${ }^{11}$

The focus so far has been on the interests of investors as investors. But feedback also has implications for deterrence because it magnifies the effects of misspeaking to the market.

Most scholars seem to agree that SFCAs offer compensation that is too generous. ${ }^{12}$ A lawsuit serves two important functions. One function is compensation: To make whole someone who suffers harm because of the actions of a wrongdoer. The other function is deterrence: To discourage wrongdoing by imposing compensation. Ideally, these two functions should complement each other. As Judge Learned Hand explained in a legendary 1947 decision, the law should provide compensation to victims only if the cost to avoid the harm is less than the cost of the harm itself. ${ }^{13}$ If compensation is too generous, there will be too many lawsuits, and people will be too careful.

To be sure, one might argue that there is no such thing as too much deterrence for fraud. But, by magnifying the market's reaction to bad news, managers will be induced to be that much more cautious when they speak, which may well have a chilling effect on disclosure generally, with the result that investors get less information than they would in the absence of SFCAs. ${ }^{14}$

11. Although it may go without saying, it makes sense to insure against risks that cannot be diversified away. One has many small appliances but only one life or house.

12. See, e.g., Spindler, supra note 1, at 77-86 (explaining that shareholder class actions dealing with fraud on the market do indeed compensate defrauded purchasers despite critiques).

13. See United States v. Carroll Towing, 159 F.2d 169, 173 (2d Cir. 1947) (holding that the liability of a defendant depends on if the burden of maintaining adequate precautions is greater or less than the probability of the plaintiff's injury multiplied by the gravity of the resulting injury). This is essentially the same point ultimately made by the Coase Theorem. See, e.g., Ronald H. Coase, The Problem of Social Cost, 3 J. L. \& Econ. 1, 8-13 (1960) (explaining that it is a judge's decision to ensure that causation results in proper legal liability being attributed to both parties). To be more precise, the Coase Theorem argues that the placement of liability does not matter if the parties can negotiate with each other. See generally, Richard A. POSNER, ECONOMIC ANALYSis OF LAW 42-48 (3rd ed. 1986) (stating that negotiations and mutually beneficial exchanges can limit damage costs for both parties and result in an increase in overall value).

14. See Frank H. Easterbrook \& Daniel R. Fischel, Optimal Damages in Securities Cases, 
Moreover, there is no reason to think that the loss suffered by investors constitutes optimal deterrence. As discussed further below, much of the loss is typically unavoidable, but can be hedged away by diversification. The effect of a misrepresentation is merely to delay disclosure of the truth, thus shifting a loss that someone must suffer from one investor to another. Think musical chairs. But this portion of investor loss can be diversified away. ${ }^{15}$

Thus, feedback magnifies deterrence that is already excessive. Because buyers can recover their entire loss (including the portion coming from the normal vagaries of business), managers must be extraordinarily careful in speaking to the market. This is especially true when a business is in flux anyway with volume and volatility at a high as it often is in the context of events that give rise to SFCAs. In such situations, the consequence of misspeaking may be to give buyers the equivalent of a free put-option against the company itself.

Although Spindler recognizes that feedback can cause damages to exceed the value of the defendant company at the extreme, he seems to argue that SFCAs do not really work as intended anyway because plaintiffs tend to settle for whatever is available from insurance and because some defendants turn out to be judgment proof. ${ }^{16}$ But it is odd to defend a legal doctrine, because in the real world it does not work as intended. ${ }^{17}$

The ultimate point of the circularity critique is that damages are excessive - and not that plaintiffs cannot be compensated. In short, Spindler's statement that feedback operates to assure full compensation utterly misses the point. ${ }^{18}$

52 U. CHI. L. REV. 611, 640 (1985) (discussing the value of nondisclosure for investors and their desire to reduce costs of finding out about firms and their securities).

15. Easterbrook and Fischel (writing in 1980 before Basic, Inc. v. Levinson, 485 U.S. 224, 227-28 (1988) and the subsequent growth in SFCAs) suggested that the excess inherent in a loss-based measure of damages might be justified as a substitute for punitive damages on the theory that many cases of fraud go undetected. Easterbrook \& Fischel, supra note 14, at 633-34. It seems much more likely today, that although many cases are dismissed for lack of merit, few, if any, meritorious claims fail to give rise to a SFCA.

16. Spindler, supra note 1 , at 97-101.

17. I am reminded of the scene in which the Sundance Kid objects to jumping into a river to escape pursuit because he could not swim, to which Butch Cassidy responds (laughing): "Are you crazy? The fall will probably kill you anyway." BUTCH CASSIDY AND THE Sundance Kid (20th Century Fox 1969). To be fair, Easterbrook and Fischel make the similar point that confusion about the correct approach to damages may avoid the excesses of a loss-based approach to damages. See Easterbrook \& Fischel, supra note 14 at 643-44 (explaining the difficulty in knowing whether loss-based measures are replacing profit-based measures due to the lack of violations by firms while trading in the aftermarket).

18. Spindler's critique of FOTM and SFCAs depends on a bit of legerdemain. By discussing circularity and diversification separately, Spindler avoids discussing conflicting stockholder preferences as by focusing first on the technical question whether it is 
It is important to recognize that securities fraud of the sort at issue in most SFCAs does not necessarily involve gain to the issuer or the individuals involved. So, there is no need for multiple damages as in cases of insider trading. ${ }^{19}$ This distinction - between fraud with gain to the fraudster and fraud without gain to the fraudster - also explains the distinction between fraud in connection with offerings by issuers (1933 Act claims) and fraud in connection with trading between stockholders (Rule 10b-5 claims). ${ }^{20}$ As Spindler notes, scholars have argued that affording investors recovery for the one does not imply they should also have a remedy for the other. But, Spindler argues that investors do not care about the identity of the fraudster, and thus that the distinction between actions arising under the 1933 Act (involving offerings) and actions arising solely under Rule 10b-5 (involving outstanding shares and open-market trading) is one without a difference. ${ }^{21}$ As he states:

Upon reflection, one sees that a sharp distinction between primary trades and secondary trades is incorrect. In a zero-sum game among secondary market traders, the players still try to win it, expending resources to do so. Diversification changes nothing, as Easterbrook and Fischel pointed out three decades ago, since all investors (even diversified) would like to win more often than not. If uninformed traders stand to fund others' "handsome profits" by trading against a better-informed party, they do not care whether that other is an issuer or someone else. ${ }^{22}$

Here again, Spindler misses the point. The argument is not about whether there should be a remedy. The question is whether the remedy should be a class action by which buyers are compensated for their losses by

mathematically possible for a class action remedy to work, which no one questions anyway. See Spindler, supra note 1, at 92-113. Cf. HB Korenvaes Investments, L.P. v. Marriott Corp., No. 12922, 1993 WL 257422, at*19-21 (Del. Ch. July 1, 1993) (measuring fiduciary duty to preferred stockholders in connection with spin-off by whether anti-dilution adjustment remained workable). He then addresses diversification solely with regard to deterrence (whether it will save investors the expense of research), thus missing entirely the peculiar (though predominant) interests of diversified investors regarding the circularity problem.

19. Moreover, since the remedy is a class action (or derivative action as proposed here), the potential for recovery extends to the entire loss. Thus, as in an ordinary consumer class action, there is no need for punitive damages if all of the victims are made whole. See Richard A. Booth, Senate Goes Back to the Future on Arbitration, CLS (ColumBia Law SchoOL) BLUE SKY BLOG (Dec. 5, 2017), http://clsbluesky.law.columbia.edu/2017/12/05/senate-goesback-to-the-future-of-arbitration/ (explaining that it is unnecessary to multiply damages if all victims are a party to the action).

20. Spindler, supra note 1 , at 68-92.

21. Id. at $84-86$.

22. Id., at 86 . 
holders. The remedy under the 1933 Act is different: With disgorgement by the company capped at the amount of the offering, the company and investors are restored to the status quo ante. There is no feedback effect. The remedy is perfectly congruent with both investor loss and fraudster gain (ignoring the expenses of litigation). ${ }^{23}$

There is no doubt that investors have an interest in deterring fraud. But whether investors like SFCAs depends on whether there is any other remedy that does not entail the collateral damage that goes with SFCAs. If not, the idea that fraud should go unpunished may be too much to swallow even though it may be in the interest of most investors to forgo any remedy. ${ }^{24}$ So investors might be willing to live with SFCAs (and the collateral damage they cause) in the absence of any alternative. Thus, Spindler's argument as to circularity ultimately depends on the non-existence of other remedies. ${ }^{25}$ In other words, the question is not whether there should be a remedy. Rather, the question is what the remedy should be. Spindler himself is agnostic about whether SFCAs are the best remedy. ${ }^{26}$ While he defends SFCAs, he does not claim that they are necessarily the best way to deal with securities fraud. But he does argue that a loss-based remedy makes sense because investors

23. See Easterbrook \& Fischel, supra note 14, at 636-39 (discussing the issue of matched gains and losses and the resulting minimal net harm). Spindler seems clearly to be focused on the investor protection function of federal securities law, but capital allocation is also an important goal. Spindler, supra note 1, at 73-77. See also Amanda Rose \& Richard Squire, Intraportfolio Litigation, 105 Nw. U. L. REV. 1679, 1702 (2011) (arguing that business-tobusiness litigation may have important effects on the cost of capital for individual businesses even though it is a zero-sum game for stockholders).

24. Nevertheless, Joseph Grundfest has proposed that the SEC could simply declare that there is no private cause of action under Rule $10 \mathrm{~b}-5$, since the SEC presumably has authority to repeal any rule it has adopted. Joseph A. Grundfest, Disimplying Private Rights of Action Under the Federal Securities Laws: The Commission's Authority, 107 HARV. L. REV. 961, 976 (1994).

25. There is considerable scholarship focused on the search for alternatives to FOTM precisely for this reason. See, e.g., John C. Coffee, Jr., Reforming the Securities Class Action: An Essay on Deterrence and Its Implementation, 106 COLUM. L. REV. 1534, 1561-66 (2006) (explaining that academics have researched securities class action in the secondary market context and have given very different responses in their research); see also Amanda M. Rose, Reforming Securities Litigation Reform: Restructuring the Relationship Between Public and Private Enforcement of Rule 10b-5, 108 COLUM. L. REV. 1301, 1325-49 (2008) (explaining that academics have conflicting responses when they critically examine private enforcement as a supplement to SEC fraud deterrence efforts). But no one has offered a workable private remedy, except the one outlined here below.

26. Spindler, supra note 1, at 113. Accord Easterbrook \& Fischel, supra note 14, at 640 (expressing skepticism about the efficacy of proposals that fasten liability on managers for harms they inflict on the securities market). Spindler's point seems to be that there should be some sort of remedy that shifts the cost of basic research onto someone who is better able to bear it. 
will expend resources as a precaution against fraud if they can avoid losses that exceed (or at least equal) the expense of precaution. ${ }^{27}$ So the question remains whether there is any better remedy for open-market securities fraud that does not entail the circularity and feedback that go with SFCAs.

As it turns out, a derivative action is just such a remedy. Moreover, as shown in the next section, a derivative action can be perfectly tailored to compensate investors and penalize fraudsters for the true losses caused by fraud. And since the company recovers from the wrongdoers, there is no feedback. Rather, market capitalization (and stock price) should rise by the amount of any recovery, thus compensating all investors pro rata.

\section{DIVERSIFICATION AND FRAUD}

Having dealt with the circularity problem to his own satisfaction, Spindler then addresses the argument that diversified investors do not care about fraud because gains and losses wash out over time. His key point is captured in the heading for Part V of the article: You Cannot Diversify Away Fraud. As he summarizes his argument:

The diversification critique fails because it is based on a core misunderstanding of what diversification does, and does not, do. In the most fundamental terms, diversification does nothing (1) to negate fraud losses or (2) to counter the incentive to guard against pricing error and asymmetric information. In any particular transaction, an investor has an incentive to guard against overpaying; if he does not, and if there is uncertainty regarding the correct price, there is a risk of being expropriated by traders with better information. Thus, the investor has the incentive to expend precaution costs, searching for the security's true price. In a form of the Prisoners' Dilemma, both buyer and seller expend search costs, and each is made worse off. This remains true in the diversified setting. If an investor buys one security and sells another, there is a risk of being expropriated, in each trade, by

27. Spindler argued: "While fraud on the market is not a panacea remedy [sic], the critics' principal complaint - that fraud on the market fails to compensate - is untrue. As demonstrated mathematically, the fraud on the market remedy of loss-based damages can perfectly compensate defrauded purchasers. The feedback effect between damages and share price declines arrives at just the right level of transfer to compensate purchasers both for the initial price inflation as well as the decline in share price due to the firm's liability." Spindler, supra note 1, at 101 (emphasis added). In contrast, Easterbrook and Fischel argued that the optimal remedy would be one based on gain to the fraudster. Easterbrook \& Fischel, supra note 14, at 640. See Spindler, supra note 1, at 78-79 (stating "that an optimal rule would tend to focus on the level of the 'wrongdoer's profits.'"). 
traders with better information; if he does not expend precaution costs, his expected gains will be systemically [sic] lower. Diversification does not guard against those systemically lower returns. Similarly, where an investor purchases (or sells) a diversified portfolio of securities, the investor certainly wishes not to overpay (or be underpaid) for that portfolio; the relatively lower firm-specific risk of the diversified asset does not moot that concern. (Drawing an example from recent history, the diversification provided by a collateralized debt obligation (better known, perhaps, as a CDO) did not moot the necessity of vetting the underlying mortgages, as the 2007 financial crisis proved.) The uninformed trader, confronted with price uncertainty and potentially better-informed traders, will face expected losses. This is true even across a multitude of trades, and without regard to whether the trades are primary or secondary in nature.

Any investor (including a diversified investor), therefore, has incentives to expend resources protecting herself from expropriation by other, betterinformed traders. Such precaution costs are analogous to the costs of guarding against theft (such as purchasing locks or moving to a better neighborhood), and constitute a deadweight loss to society. An extensive financial economics literature details the problems created in such an environment: illiquidity, adverse selection, and wasteful investment in research and misreporting technologies. As just one facet of the magnitude of such costs, a recent estimate puts the amount of money under active professional management at more than $\$ 60$ trillion in 2012, generating (conservatively) at least $\$ 600$ billion of active management fees per year (not including performance-based fees); these are precaution costs. Such costs, of course, do not diversify away. ${ }^{28}$

To be clear, Spindler makes two points here. One relates to the power of diversification. The other relates to who should bear the cost of disclosure.

As for the power of diversification, Spindler is technically correct that one cannot diversify away fraud - at least not true fraud. True fraud always works to the advantage of the fraudster and against counterparties. ${ }^{29}$ But

28. Spindler, supra note 1, at 71-72 (footnotes omitted).

29. I have made the similar argument that the business judgment rule protects only decisions that involve diversifiable risks. Because decisions tainted by a conflict of interest are at best fair to minority stockholders, and because decisions to undertake deals that at best can break even are no-win transactions, such decisions are not protected by the business judgment rule because the robust protections of diversification expected by common stockholders do not apply. See Richard A. Booth, Stockholders, Stakeholders, and 
Spindler is not talking only about true fraud. As noted above, securities fraud relating to open-market trading in outstanding shares (under Rule 10b-5) is peculiar in that the fraudster does not usually gain from the fraud. Although the fraudster may gain (for example, where a CEO sells her own shares before disclosing bad news - a classic case of insider trading) most cases do not involve insider gain. And those that do may result in criminal prosecution or a claim by the corporation essentially for unjust enrichment. ${ }^{30}$ Rather, in a case of open-market fraud the gain (or loss avoided) goes to other stockholders - outsiders - who just happen to sell during the fraud period. ${ }^{31}$ It is a bit odd to call this fraud since the fraud (if any) is perpetrated for the benefit of someone other than the fraudster. To be sure, it can be argued that managers may be motivated to keep stock price high just in case they want to sell their shares (and incidentally for the benefit of existing stockholders). But we generally expect (and want) managers to maintain the highest possible stock price. ${ }^{32}$ Thus, we might call this quasi-victimless offense inflation fraud to distinguish it from classical fraud where the perpetrator seeks to cheat the victim. ${ }^{33}$

Bagholders (or How Investor Diversification Affects Fiduciary Duty), 53 THE BUS. LAWYER 429, 468 (1998) (stating that conflicts of interest may induce management to inflict losses on a business).

30. See Kahn v. Kolberg Kravis Roberts \& Co., 23 A.3d 831, 837 (Del. 2011) (abrogating Pfeiffer to extent that it held corporations could not recover for insider gains); Brophy v. Cities Service Co., 70 A.2d 5, 7 (Del. Ch. 1949) (holding that there is a cause of action against an employee who trades based on confidential information).

31. One might argue that the problems with SFCAs could be fixed by holding sellers liable for the (effective) gains they enjoy from selling at an inflated price, however impractical it might be to do so. Cf. Henry Hansmann \& Reinier H. Kraakman, The Uneasy Case for Limiting Shareholder Liability in Tort, 100 Y ALE L. J. 1879, 1880 (1991) (arguing that limited liability should be abolished). But it is important to permit sellers to retain their gains for diversification purposes - to be netted out against buy-side losses.

32. The law does not require companies or their managers to disclose everything investors would want to know. Moreover, there may be good business reasons to delay public disclosure of news (whether good or bad), for example, to facilitate negotiations. But generally speaking, no such justification can excuse a positive misrepresentation. See Basic Inc. v. Levinson, 485 U.S. 224, 227-28 (1988) (noting that misrepresenting information to induce a reliance upon a false statement is fraud; In re Time Warner, Inc. Sec. Litig., 9 F.3d 259, 267 (2d Cir. 1993) (noting that corporations need not disclose information because investors want to know it).

33. To be clear, the courts do not generally make much of a distinction between these two varieties of fraud, although concomitant insider trading is usually sufficient to establish scienter - one might call it scienter per se. See Richard A. Booth, The Missing Link Between Insider Trading and Securities Fraud, 2 J. Bus. TECH. L. 185, 193 (2007) (stating that scienter can be established by identifying unusual insider trading activity at the same time a fraud occurred). Note also that the benefit (if any) to the fraudster in cases of inflation fraud is typically far less than any class claim. See, e.g., Fridrich v. Bradford, 542 F.2d 307, 323 (6th 
The central point is that outsiders are equally likely to benefit from inflation fraud as they are to suffer losses from it. Accordingly, diversification does indeed afford protection against inflation fraud. In contrast, claims arising under the 1933 Act are quite different since the issuer is the primary beneficiary. Thus, issuer liability (through disgorgement) makes perfect sense. ${ }^{34}$

Cir. 1976) (reversing judgment against buyers in private insider trading case under which they would have been required to compensate all sellers for their losses). In addition, the word fraud is sometimes used to describe a breach of fiduciary duty - particularly a breach of the duty of loyalty (DOL). This too is a bit of a stretch on classical concepts. Embezzlement is not really fraud. It is theft. Here the Supreme Court has weighed in emphatically to hold that fraud under Rule 10b-5 requires deceit - and thus speech. See Stoneridge Inv. Partners, LLC v. Scientific-Atlanta, Inc., 552 U.S. 148, 159 (2008) (noting that under Rule 10b-5 liability cannot be imposed absent a public statement); see also Santa Fe Indus., Inc. v. Green, 430 U.S. 462, 476 (1977) (holding that fiduciaries treating shareholders unfairly but without deception, misrepresentation, or nondisclosure are not violating Rule 10b-5). Then again, it seems clear that insider trading and broker churning are recognized forms of securities fraud that do not in fact require speech precisely because the fraudster is subject to a fiduciary duty. See United States v. O'Hagan, 521 U.S. 642, 652 (1997) (holding that an attorney was liable for trading on insider information of client company because of a fiduciary duty).

34. It is also curious that 1933 Act violations have come to be called fraud since the act establishes a no-fault strict liability regime that affords investors a remedy for any misstatement or omission of a material fact by an issuer in connection with an offering. But it is easy to see how the law implied an additional remedy for the victims of open-market inflation fraud. When a public company makes a public offering of additional shares, it can be difficult or impossible to determine who bought the new shares. See In re Transkaryotic Therapies, Inc., No. 1554-CC, 2007 Del. Ch. LexIs 57, at *8-13 (Del. Ch. May 2, 2007) (showing that it is difficult to ascertain who a beneficial owner of a stock is). But because issuer liability under the 1933 Act is limited to the amount of the offering, tracing is required to prove a claim. See Barnes v. Osofsky, 373 F.2d 269, 272 (2d Cir. 1967) (holding that the plain reading of the 1933 Act is that tracing is required to prove a claim). Since investors who buy in the aftermarket cannot prove that the shares they buy are part of the offering, it seems only fair to permit them to claim under Rule $10 \mathrm{~b}-5$ if they can satisfy the heightened requirements that they relied on a misrepresentation in the prospectus and that the issuer acted with scienter. Indeed, one might argue that the issuer company in such cases derives a direct benefit from keeping stock price high, to wit assuring the success of the offering. See Easterbrook \& Fischel, supra note 14, at 636-39 (noting that purchasers of the first issue in the aftermarket can bring a suit against the issuer because the issuer caused the inflated price just as the issuer inflated the new price). In any event, it is standard practice in the context of 1933 Act claims also to make a claim under Rule 10b-5. See Herman \& MacLean v. Huddleston, 459 U.S. 375, 387 (1983) (holding that the availability of a 1933 Act claim does not preclude a Rule 10b-5 claim). It is a small step from there to making a stand-alone claim under Rule 10b-5. See Richard A. Booth, The Missing Link Between Insider Trading and Securities Fraud, 2 J. Bus. TECH. L. 185, 194 (2007) (noting that it became normal practice to add a Rule 10b-5 claim to all claims under the $1933 \mathrm{Act}$ ). Nevertheless, it is puzzling to hold the company liable for misrepresentations made by its agents. The usual explanation is that this is a form of vicarious liability, as in cases of tort. See Restatement (ThiRD) Of AGENCY $§ 7.08$ (AM. LAW INST. 2006) (citing a case wherein a city was held vicariously liable 
As for who should bear the cost of disclosure, Spindler seems to define fraud to include any situation in which one party to a trade is better informed than the other. He argues that if some investors do research, all investors must do research as long as the expense thereof is less than the gain (or loss avoided). ${ }^{35}$ Otherwise, investors who do research will gain at the expense of investors who neglect to do research. So, investors do better in the aggregate by shifting the cost of research to issuers in the form of mandatory disclosure together with rules against fraud. And issuers enjoy a lower cost of capital to boot. ${ }^{36}$ Thus, Spindler argues that investors would be worse off without SFCAs because they would then be forced to do research that is cheaper to handle by mandatory disclosure. In other words, his argument is a Coasean one that SFCAs shift the cost of fraud (as he broadly defines it) onto issuers as the cheaper cost avoiders. Indeed, it is arguably costless for companies or their managers to avoid misrepresentation. In any event, SFCAs relieve individual investors of the need to verify issuer reporting. Or so the argument goes. ${ }^{37}$

for a police officer's violations of federal law under ordinary tort principles); WILLIAM T. ALlen \& Reinier KRAaKman, Commentaries and CASES ON THE LAW OF Business ORGANIZATION 27 (5th ed. 2016) (noting that apparent authority is also a basis for imposing vicarious liability). But it would seem more precise to see the misrepresentation as the act of the company itself through its agents, as in cases of contract.

Incidentally, Spindler's parenthetical aside - that losses from CDOs demonstrate the limits of diversification - fails to recognize that in the stock market losses can be offset by gains because companies sometimes do better than expected. But an investor who holds nonconvertible bonds can never do better than be paid the agreed return. This is not to say that diversification has no value in connection with investments in debt securities. Rather, it is only to say that it does not work as powerfully as it does with investments in common stock.

35. Without this limitation, research would spiral into an arms race: As some investors increase spending on research, all will do so ad infinitum. This argument is a variation on the efficiency paradox: If the market is efficient, investors will stop doing research, and the market will no longer be efficient. The answer to this paradox is that as the market becomes inefficient, investors do just enough research to exploit the inefficiencies. So, the fallacy in the paradox inheres in looking at a dynamic system as if it must result in an all-or-nothing solution rather than an equilibrium. SFCAs tend to destabilize this equilibrium by magnifying the effects of any errors in disclosure.

36. Spindler concedes that if investors were somehow precluded from doing research, they would be equally well off, but he dismisses this scenario as an unrealistic or degenerate case. Spindler, supra note 1, at 106. See generally Paul G. Mahoney, Precaution Costs and Fraud in Impersonal Markets, 78 VA. L. REV. 623, 638 (1992) (discussing the distinction between informed and uninformed investors).

37. Nevertheless, some scholars have questioned the value of mandatory disclosure because, arguably, issuers would provide such information anyway in their own self-interest to minimize the cost of capital. See generally Paul G. Mahoney, Mandatory Disclosure as a Solution to Agency Problems, 62 U. CHI. L. REV. 1047, 1048 (1995) (presenting an efficiency justification for mandatory disclosure in security markets). By extension, there should be no need for any legal remedy as an inducement: Companies will do the right thing because they 
Spindler is correct that the expense of precautions against true fraud is a deadweight loss. ${ }^{38}$ So the law should impose a remedy shifting that loss to whomever can avoid it at the least expense. Spindler makes no distinction between precaution and research. He seems to see all investor research as directed at detecting fraud (or at least misinformation). Thus, he argues that companies should be liable for both. But unless one assumes that market prices are normally accurate (as opposed to merely efficient), it seems unlikely that investors spend much on detecting fraud. It seems much more likely that investor spending relates to efforts to beat the market - to identify instances of mispricing.

Spindler seems not to notice the irony in his observation that investors spend as much as $\$ 600$ billion annually on management fees that pay for research in a system that already provides for mandatory disclosure as well as a remedy for fraud in the form of SFCAs. ${ }^{39}$ Moreover, and perhaps more important, Spindler also fails to notice that because feedback causes additional loss, investors will spend that much more on precaution. In other words, there is good reason to think that SFCAs (by magnifying losses from fraud) induce investors to waste even more resources on precaution than they otherwise would do. ${ }^{40}$

Again, Spindler seems to assume that SFCAs are the only possible remedy. If there is some other remedy that would better induce issuers to provide the appropriate level of disclosure, presumably even Spindler would agree that SFCAs should be abolished. The question is whether there is some other remedy that might do the job better. The answer can be found in a careful analysis of the losses that can be recovered in an SFCA.

The extant rule is that buyers may recover the difference between purchase price and the price following corrective disclosure (as adjusted for any changes attributable to other causal factors, including background

want to do the right thing - like doing the dishes as famously argued in the movie The Break Up. The Break-Up (Universal Pictures 2006). But even Pangloss would allow that some companies may cheat. See generally Voltaire, CANDide (1759) (passim) (where Pangloss, a pedantic tutor, is known for his fervent, yet misguided optimism). Thus, few seriously question the value of mandatory disclosure or a remedy for fraud (as properly defined).

38. Spindler, supra note 1, at 71-72.

39. The $\$ 600$ billion figure is apparently based on an estimate that US investors hold about $\$ 60$ trillion in equity and debt combined and spend about one percent thereof on investment management. See B.101 Balance Sheet of Households and Nonprofit Organizations, BOARD OF Governors OF THE Federal Reserve System (Mar. 9, 2017), htt ps://www.federalreserve.gov/releases/z1/20170305/html/b101.htm (listing various assets and liabilities of households and nonprofits).

40. One could argue that if the remedy worked to prevent fraud, feedback would be eliminated, too. But in the real world, fraud seems to persist. 
changes in market prices generally). But this measure of damages comprises several different components of loss, some of which are diversifiable. Moreover, it turns out that the losses that cannot be diversified away are all derivative in character and should give rise to a claim on behalf of the company rather than against the company. Since other losses can be hedged away by holding a diversified portfolio, it follows that SFCAs should be abolished in favor of derivative actions.

Consider the following example. ABC Company trades at $\$ 10$ per share on expected earnings of $\$ 1.00$ per share. Thus, the market applies a $10 \%$ discount rate to $\mathrm{ABC}$. In other words, investors demand a $10 \%$ return on an investment in $\mathrm{ABC}$ stock. A big customer of $\mathrm{ABC}$ cancels a contract, which will result in a decrease in earnings to $\$ 0.90$ per share. Other things equal, one would expect the market price of $A B C$ stock to decrease to $\$ 9$ per share. But as a result of the contract cancellation, the market has reassessed the risk inherent in $\mathrm{ABC}$ and now imposes a $12 \%$ discount rate. Thus, the price of $\mathrm{ABC}$ stock falls further to $\$ 7.50$ per share. ${ }^{41}$

If $\mathrm{ABC}$ discloses the contract cancellation promptly. No one has a claim as a result of the decline in stock price. The losses suffered by investors are ordinary run-of-the-mill losses that result from business risks that investors willingly assume. As such, these losses can be diversified away. They come out in the wash because on average and over time for every $\mathrm{ABC}$ there is an $\mathrm{XYZ}$ that enjoys unexpected gains.

Now suppose that the $\mathrm{CEO}$ of $\mathrm{ABC}$ covers up the news of the contract cancellation and the truth does not come out until ten months later. As a result, investors who bought $\mathrm{ABC}$ stock during the ten-month fraud period have a claim against the company for their loss. But the loss may well be greater than the original $\$ 2.50$ per share loss. For example, as a result of the cover-up the market may lose trust in management and impose a higher $15 \%$ discount rate. If so, stock price will fall to $\$ 6.00$ per share. ${ }^{42}$ In addition, the market may estimate that increased legal fees and a potential SEC fine will further reduce company value by $\$ 1.00$ per share because of the drain on cash. So, the market may further bid down stock price to $\$ 5.00$ per share. Thus, what would have been a $25 \%$ decrease with prompt disclosure has become a $50 \%$ decrease because of the cover-up. ${ }^{43}$

In all likelihood, this $50 \%$ loss will be further magnified by feedback because the market will likely assume that a meritorious SFCA will be filed. ${ }^{44}$ But ignoring the feedback effect for the moment, $\mathrm{ABC}$ stock price

\footnotetext{
41. $0.90 / 0.12=7.50$

42. $0.90 / 0.15=6.00$

43. $1-(7.50 / 10.00)=0.25 ; 1-(5.00 / 10.00)=0.50$.

44. This $50 \%$ decrease will be magnified by the feedback effect. Assuming that the
} 
would have fallen by $25 \%$ even with prompt disclosure. Instead, it has fallen by $50 \%$ because of the cover-up. Presumably, even Spindler would agree that stockholders have no claim in the absence of the cover-up and that the first $25 \%$ loss can be diversified away. The fact that a SFCA has been filed does not alter the fact that half of the loss is diversifiable. This portion of the loss remains diversifiable irrespective of the cover-up.

The additional $25 \%$ loss that flows from the cover-up is different. In the absence of the cover-up, ABC stock price would have been $\$ 7.50$ per share. Instead, it has fallen to $\$ 5.00$ per share because of the cover-up. The additional $\$ 2.50$ decline is a deadweight loss that cannot be diversified away. There is no prospect of an offsetting gain from another company because of the absence of fraud. There is no reward for good behavior - except maybe in prison. Moreover, and perhaps more important, it is a loss that could have been avoided if the CEO had not covered up the facts.

This is a loss that is suffered by all of the stockholders (both those who bought during the fraud period and those who held their stock from before), because the value of the corporation has fallen by an additional $\$ 2.50$ per share as a result of management misbehavior. As such, this additional loss is properly characterized as derivative rather than direct. It is a loss for which the corporation should recover against the individual wrongdoers. ${ }^{45}$

Needless to say, the corporation itself has no claim based on lower than expected returns or a higher cost of capital because of an increase in business risk perceived by the market. And legacy stockholders have no gripe as to the first $\$ 2.50$ loss. They would have lost the first $\$ 2.50$ per share no matter what. But this loss can be diversified away. Indeed, the sales lost by ABC were likely gained by some XYZ. Although fraud-period buyers do have a claim for the first $\$ 2.50$ as the law currently stands, it is not clear that they should do so since this is a loss that must be suffered by someone. Think musical chairs. Perhaps more to the point, the timing of the loss (whether it is disclosed immediately or at some later time) is irrelevant to whether it can be diversified away. There is no reason to think that diversification does not work to net out unexpected losses and gains over time. Indeed, there is every reason to think that diversification works better over longer periods of time.

plaintiff class comprises $40 \%$ of ABC stockholders, and assuming the market thinks the SFCA will be wholly successful, stock price will fall to $\$ 1.66$ because of feedback: $0.50 /(1-0.40)$ $=0.50 /(0.60)=0.8333$. Thus, a $50 \%$ loss becomes an $83.33 \%$ loss.

45. The extra (and avoidable) loss in the example derives from an extra increase in the discount rate and from the prospect of a cash outflow. There may also be cases in which lower returns can be traced to actionable misbehavior. For example, management may have misrepresented the quality of its products and caused customers to cancel orders. But that would give rise to a derivative claim, just as does an increase in the cost of capital from a loss of trust or a cash outflow. 
For the law to provide recovery for inevitable and diversifiable losses constitutes a windfall for investors who just happen to buy during the fraud period: Buyers end up better off than they would have been in the absence of fraud if the law provides recovery for losses that can be diversified away. Moreover, deterrence becomes excessive - which is, not to mention, the additional deterrence from feedback or the fact that it is misguided because the company pays. ${ }^{46}$ To be sure, buyers never recover in full. But the problem is that the company pays at all when it is the company that should receive any recovery. ${ }^{47}$

The bottom line is that after netting out diversifiable losses, there is nothing left other than derivative claims. Because he fails to sort out the elements of harm, Spindler fails to notice that the only losses that matter are derivative in nature and that a derivative action is perfectly tailored to provide both compensation and deterrence. Then again, no one else seems to have noticed this distinction either.

\section{DIVERSIFICATION AND MISPRICING}

Assuming that fraud (intentional misrepresentation) can be addressed by means of a derivative action as outlined above, what should we do about the remainder of the loss suffered by investors who buy (or sell) during the fraud period? The short answer is: Nothing.

46. To complicate matters further, the additional loss from feedback should also give rise to a derivative claim. But it would be odd for the company to compensate buyers, as under extant law, and then to seek recovery from the individual wrongdoers. At the very least, this scenario should suggest that the recovery from the individual wrongdoers should go to the buyers. In practice, this contradiction is effectively ignored by settling parallel derivative actions for non-monetary governance reforms of dubious value.

47. The implicit assumption here is that the excess loss - the derivative claim - is the correct level of deterrence. To be sure, this ordinary tort approach may not suffice in cases in which the wrongdoer stands to gain. Although it seems likely that the derivative loss will usually exceed any personal gain — probably many times over - the general rule is that wrongdoers must also disgorge any gain. See Kahn v. Kolberg Kravis Roberts \& Co., L.P., 23 A.3d 831, 838 (Del. 2011) (noting that it is an act of disloyalty for a fiduciary to profit from information obtained through a confidential relationship, even if the advantage was not gained at the expense of the fiduciary); see also Brophy v. Cities Servs. Co., 70 A.2d 5, 8 (Del. Ch. 1949) (maintaining that an employee cannot use secret corporation information for his own personal gain). But see Tarnowski v. Resop, 236 Minn. 33, 39 (1952) (holding an agent liable for both damage done to a principal's business and improper benefits (bribes) received in connection with service as an agent); $c f$. Easterbrook \& Fischel, supra note 14, at 634-35 (discussing tension between damages based on plaintiff loss and defendant gain). Note also that a direct claim by buyers compensates only buyers for their share of the derivative loss. The whole of the derivative loss may be greater than or less than the whole of the direct (SFCA) recovery. 
Spindler argues that even diversified investors prefer to win (or at least not to lose) in any given transaction:

The diversification critique fails because it is based on a core misunderstanding of what diversification does, and does not, do. Similarly, where an investor purchases (or sells) a diversified portfolio of securities, the investor certainly wishes not to overpay (or be underpaid) for that portfolio; the relatively lower firmspecific risk of the diversified asset does not moot that concern. (Drawing an example from recent history, the diversification provided by a collateralized debt obligation (better known, perhaps, as a CDO) did not moot the necessity of vetting the underlying mortgages, as the 2007 financial crisis proved.) The uninformed trader, confronted with price uncertainty and potentially better-informed traders, will face expected losses. This is true even across a multitude of trades, and without regard to whether the trades are primary or secondary in nature. ${ }^{48}$

In essence, the argument is that a diversified investor can get killed by a thousand tiny cuts. Spindler reasons that although an investor may minimize risk through diversification, a diversified investor still has reason to take precautions - albeit a somewhat reduced reason. Spindler observes that if we think about each individual trade made by a diversified investor, it is clear that she would prefer to buy or sell at a good price and would at least worry that the price is skewed against her because other traders have better information. ${ }^{49}$

In the end, it is Spindler who misunderstands the effects (and power) of diversification: By holding and maintaining a balanced portfolio of twenty or more stocks, an investor can eliminate almost all of the risk that goes with investing in one stock - about $70 \%$ of total risk. ${ }^{50}$ The law of large numbers dictates that over time and on average purchases of overpriced stocks will be offset by purchases of underpriced stocks. ${ }^{51}$ Ditto for sales ceteris paribus.

48. Spindler, supra note 1 , at 71 .

49. Id. Note that Spindler seems to be talking here about asymmetric information generally - about the fact that investors worry that other investors may know more. On the other hand, it could be that Spindler thinks that all asymmetry should be seen as fraud. See also Easterbrook \& Fischel, supra note 14, at 639-44 (noting that aftermarket fraud may give rise to net harm but that it is likely to be a good deal smaller than the gross transfer of wealth between sellers and buyers).

50. See Burton G. Malkiel, A Random Walk Down Wall Street 227-50 (1996) (noting that an investor can eliminate investment risk by having a balanced portfolio of stocks).

51. See Easterbrook \& Fischel, supra note 14, at 641 (stating that most gains and losses in the market net out). 
And all the more so where one engages in many trades. ${ }^{52}$ In other words, through diversification an investor can eliminate all of the firm-specific risk that goes with investing in an individual stock without any sacrifice of return. The only remaining risk is market risk - the risk that the value of equity in the aggregate will rise or fall. ${ }^{53}$

It may be true that diversified investors worry about mispricing, but the question is whether they would (or should) spend anything to identify mispriced stocks given that they have hedged away the risk thereof by virtue of being diversified. In other words, if one knows that occasional mispricing will wash out, would one nevertheless spend (just a bit maybe) to identify mispriced stocks so as to squeeze out a little more return? After all, the fact that one is protected from loss does not necessarily mean that one would leave money on table.

Or does it? The little-noticed flip-side of eliminating downside risk is eliminating upside potential. ${ }^{54}$ In other words, a diversified investor is protected against the risk of loss from normal (random) fluctuations in price. But the protection is purchased using the random gains that come from the same source. ${ }^{55}$

Consider the following model: Imagine a world with two companies. Gunco is a defense contractor. ${ }^{56}$ In wartime, it generates a return of $20 \%$ while in peacetime it generates zero return. Butterco is a consumer products company. In peacetime, it generates a $20 \%$ return while in wartime it generates zero return. Assume further that there is a fifty-fifty chance of war or peace in any given year. Thus, the expected return for both companies is

52. Spindler, supra note 1 , at 82-83.

53. See MALKIEL, supra note 50, at 242 (noting that only market risk remains when risk is minimized by a diversified portfolio).

54. It may be that confusion about how diversification works is partly a result of confusion about the meaning of risk itself. The essence of risk is volatility. It is not solely about the danger of loss. It is also about the danger of gain (so to speak). Diversification is a two-edged sword. While one can eliminate company-specific risk by holding a diversified portfolio of stocks, diversification also eliminates the possibility of extraordinary gains.

55. Thus, Spindler's parenthetical (quoted above) that CDOs demonstrate the limitations of diversification misses an important difference between debt and equity - that returns on equities can exceed expectations whereas returns on debt cannot. As noted above, the maximum return one can receive with a debt instrument is the promised return (assuming purchase at par). One can never do better unless interest rates fall generally or the risk inherent in the issuer business declines. The promised return is the most one can expect.

56. William W. Bratton, Corporate FinanCe CASES AND Materials 95-98 (7th ed. 2012). The following model is based on the "Diversification as a Means of Reducing Risk" in Victor Brudney and Marvin Chirelstein's Corporate Finance. VICTOR BRUDNEY \& MARVIN Chirelstein, Corporate Finance 995-99 (1st ed. 1972). See also Malkiel, supra note 50, at 236-37 (hypothesizing that a diversified portfolio's return is constant irrespective of situational factors). 
$10 \%$ per year. Now suppose that you have $\$ 1000$ to invest. If you invest all of your money in either Gunco or Butterco, you can expect a return of $\$ 200$ half of the time - $\$ 100$ on average. But in some years your return will be zero while in others it will be $\$ 200$. It is possible that you will enjoy several consecutive years of $\$ 200$ returns, but it is also possible that you will suffer several consecutive years of zero returns. On the other hand, if you invest $\$ 500$ in each company, your return will be $\$ 100$ per year no matter what. In wartime, a $\$ 500$ investment in Gunco returns $\$ 100$, while Butterco returns zero. In peacetime, a $\$ 500$ investment in Gunco returns $\$ 100$, while Butterco returns zero. Thus, a diversified portfolio generates a $10 \%$ return no matter what happens. The expected return is $10 \%$ whether there is war or peace. ${ }^{57}$

The question for present purposes is whether a rational investor would spend anything on research (precaution) under the conditions posited by the model. Clearly not. Once we have locked in the expected return at zero risk, there is nothing to be gained. The only effect of doing research is to reduce net return by the amount spent. Thus, the notion that an investor might follow a diversification strategy and nevertheless do some research is nothing but double-think. One might argue that it is possible to generate a $20 \%$ return by choosing one or the other company as the investment for the year. But the chances of a $20 \%$ return are exactly the same as the chances of a zero return. Similarly, one might argue that it might be possible to know if there will be war or peace. But that is only to wish that the facts were different. Ultimately, the idea that one can find stocks that will do better (or worse) than they are expected to do is a self-contradiction.

Needless to say, the above model is unrealistic, but only because it posits two stocks that perfectly mirror each other (whose expected returns are perfectly inverse to each other). In the real world, most stocks move up and down together (albeit in varying proportions) and not opposite each other. ${ }^{58}$ Thus, it is impossible to eliminate the risk that stocks in general (the market) will rise or fall. But we are concerned here only with firm-specific risk. $^{59}$ And it is quite possible to eliminate the risk that any given firm will

57. In statistical terms, the standard deviation of the diversified portfolio is zero. There is no risk. In contrast, the standard deviation of each individual stock is a whopping $14.1 \%$ on a $10 \%$ expected return.

58. There are a few stocks - for example, those of gold-mining companies — that tend to move opposite the broader market. But there are too few such stocks to go around. And their value for hedging purposes has likely been dissipated. In other words, the prices of such stocks have been bid up because of their value for hedging.

59. As Judge Easterbrook states: "Securities laws require issuers to disclose firm-specific information; investors and analysts combine that information with knowledge about the competition, regulatory conditions, and the economy as a whole to produce a value for stock.Acme Propane, Inc. v. Tenexco, Inc., 844 F.2d 1317, 1323-24 (7th Cir. 1988). Just as a 
perform differently than expected relative to the market by holding the market. Indeed, the fact that the model is based on just two stocks with equal expected return and risk effectively understates the power of diversification in the real world where it is common practice to hold 500 or more stocks. ${ }^{60}$

In the end, the model depends only on the notion that stock prices move randomly (unpredictably). This assumption is consistent with real world results. There is little doubt that the market is weak-form efficient: It is impossible to predict the next move in price from the last move in price. In other words, there is a fifty-fifty chance that a given stock is over-priced or underpriced at any given moment. So, the odds are even that the next change in price will be up instead of down. Or vice versa. ${ }^{61}$

Spindler is correct that it is rational to spend on research if the cost is less than (or even equal to) the benefit. But if the benefit is zero, no cost can be justified. The point is not that one cannot beat the market but rather that there is no reason even to try if risk can be eliminated. Diversified investors might want to win with every trade but only if it is completely costless to do so.

It follows that a diversified investor must minimize expenses. Since there is no benefit that can come from spending on research, to spend anything more than the minimum for investment management is a waste of money that serves only to reduce net return. Diversified investors should be opposed to SFCAs for the same reason, since SFCAs purport to compensate investors (at least in part) for losses that can be diversified away. So, the cost of this protection is itself a deadweight loss.

Nevertheless, it seems possible for some investors to obtain better firmspecific information. For example, an investor might somehow figure out that Gunco should be expected to generate a 30\% return if war breaks out. If this prediction is based on material nonpublic information obtained improperly from within the company, there are remedies for that although

firm needn't disclose that $50 \%$ of all new products vanish from the market within a short time, so Commonwealth Edison needn't disclose the hazards of its business, hazards apparent to all serious observers and most casual ones." Wielgos v. Commonwealth Edison Co., 892 F.2d 509, 515 (7th Cir. 1989).

60. It is no worry that companies generate different rates of return as long as the rate of return is proportional to the risk inherent in each company. And the possibility that the market may get it wrong is itself a risk that disappears with diversification.

61. See 2015 IBbotson Stocks, Bonds, Bills, AND Inflation (SBBI) ClassiC YEARBOOK 90-97 (2015) (recording changes in stock prices); MALKIEL, supra note 50, at 16493 (stating the benefits of maintaining a diversified portfolio, instead of attempting to predict the future price of stock). 
they may not always work perfectly. ${ }^{62}$ But if this information (so called) is really a matter of opinion - based on new analysis of available information - it is not worrisome. Indeed, the market would not work if traders did not have differing opinions about stock values.

Few would argue that it is problematic that better information comes out over time and that market price may change as a result or indeed that some traders may gain therefrom as first movers. Investors expect prices to change. An investor cannot decline to invest simply because of the worry that the price of a stock may go up or down (thus implying that the current price is somehow incorrect). Moreover, ordinary investors (including diversified investors) are better off if market prices adjust faster to new information. And the best way to assure rapid adjustment is for those with better information to trade on it. ${ }^{63}$

Spindler assumes that investors care equally about all forms of asymmetric information. Wrong. Investors care about fraud because it causes stock prices to diverge from fair price. But passive investors do not necessarily care if active investors have better information, even if it means passive investors lose a bit in a given trade. Indeed, passive investors gain from research by active investors because it causes stock price to converge on fair price, increasing market efficiency (and integrity), which is all quite consistent with the policy behind FOTM. In other words, passive investors free-ride on the efforts of active investors. ${ }^{64}$ So passive investors should not

62. See Insider Trading and Securities Fraud Enforcement Act of 1988, Pub. L. No. 100704, 102 Stat. 4677, (1988) (current version at 15 U.S.C. 78t-1 (2018)) (providing for a treblethe-gain fine in cases of insider trading); Securities Exchange Commission, 17 C.F.R. $\S$ 243.100 (2000) (prohibiting selective disclosure by public companies).

63. There is no reason for active investors to engage in research unless they can capture some gain by doing so. Cf. Dirks v. SEC, 463 U.S. 646, 658 (1983) (noting that to outlaw trading on all nonpublic information would discourage investors from doing research). By conflating fraud with unequal information generally, Spindler misses the point that there is good asymmetry and bad asymmetry. In any event, securities law does not seek to assure equal information. It seeks only to provide the facts that a reasonable investor would want to know. See TSC Indus., Inc. v. Northway, Inc., 426 U.S. 438, 447 (1976) (stating that disclosure requirements seek to provide information that a reasonable investor might consider important in order to enable informed decision making). Incidentally, the ongoing debate over electronic trading is essentially parallel: Is it better for trades to be executed as quickly as possible before prices change or is it better to gather as many orders as possible so as to discover the best price? It is also reminiscent of the Heisenberg Uncertainty Principle: It is ultimately impossible for markets both to adjust rapidly to new information and to assure that everyone gets the same price. One must choose speed or perfectly equal treatment.

64. One might say that passive investors - indeed most investors — are price-takers in the argot of economics. The same is true in the debt market. Indeed, auctions of treasury securities are set up to accommodate such investors by permitting bidders to submit noncompetitive bids to purchase specified amounts of an offering at whatever price is 
object to paying a bit by ceding some gain to active investors. ${ }^{65}$ After all, there is no such thing as a free lunch.

In sum, the power of diversification does not depend on the accuracy of market pricing. Indeed, the greater the chances of mispricing, the more important it is for an investor to diversify. If market prices were $100 \%$ accurate, there would be no need to diversify. But neither would there be any reason to engage in costly research.

Still, even if the market is weak-form efficient, as seems certain, it is conceivable that stock prices are skewed to the high side. Spindler and others have argued that issuers are motivated to maintain high stock prices for the benefit of current stockholders. After all, there are only two things one can do with shares that one owns: One can hold. Or one can sell. And even though a stockholder may have no existing plan to sell, it is preferable for the issuer to keep stock price as high as possible just in case one decides to sell. $^{66}$ If the market is so skewed, investors will quite rationally spend on

established by competitive bidding.

65. By extension, one could argue that passive investors should be happy to allow active investors to recover via SFCAs and that feedback losses operate as a tax of sorts on diversified investors that ultimately supports the research of active investors. See Jill E. Fisch, Confronting the Circularity Problem in Private Securities Litigation, 2009 WIs. L. REV. 333, 347 (2009) (noting that indexing is devastating to markets because it makes everyone a free rider). This is a variation on the efficiency paradox that if investors really believed in market efficiency they would stop doing research, and the market would cease to be efficient. The problem is that much, if not most, of the recovery goes to random free-riding passive investors who happen to have bought during the fraud period. See Paul G. Mahoney, Precaution Costs and Fraud in Impersonal Markets, 78 VA. L. REV. 623, 627-34 (1992) (discussing the difficulties around fraud deterrence in light of passive investors). Moreover, most research is focused on identifying mis-valued stocks. Few investors engage in research to ferret out fraud. Nor is it likely that research will expose fraud. Thus, research begins where mandatory disclosure ends. So, it makes no sense to provide a remedy. Finally, active traders do not need compensation. They will do the research anyway.

66. See James C. Spindler, Optimal Sanctions for Misreporting when Shareholders Desire Fraud 3 (Nov. 17, 2017) (unpublished manuscript), available at https://ssrn.com/a bstract=3121230 [https://perma.cc/EU6R-UW2P] (discussing issuer incentive for elevated share prices based on stockholder preference for higher reported value); James C. Spindler, Vicarious Liability for Bad Corporate Governance: Are We Wrong About Rule 10b-5?, 13 AM. L. \& ECON. REV. 359, 367-74 (2011) (discussing maximization of shareholder welfare through the preservation of elevated stock prices); see also Lawrence E. Mitchell, The "Innocent Shareholder": An Essay on Compensation and Deterrence in Securities ClassAction Lawsuits, 2009 WIS. L. REV. 243, 245-47 (2009) (discussing shareholder responsibility for market integrity). Indeed, we know from experience with SFCAs that bad news cases outnumber good news cases by about fifty-to-one. In other words, the vast majority of SFCAs involve situations in which the issuer has covered up bad news presumably in an effort to keep stock price higher than it should be - inflated as the courts tend to say. But the skew in SFCAs may also be the result of feedback or the seemingly natural tendency to delay disclosure of bad news. 
precaution - a deadweight loss that could be avoided if we could deter fraud.

There are several responses. First, if there is a tendency for stock prices to be inflated, there is every reason to believe that the market will discount stock prices accordingly. Second, there is reason to believe that stock prices tend to be a bit low. The Delaware courts have held that market prices do not constitute competent evidence for appraisal purposes because they reflect an inherent discount (possibly because deal price almost always includes a premium over market price). ${ }^{67}$ Indeed, appraisal awards on the average equal about $150 \%$ of pre-deal market price. ${ }^{68}$ Moreover, stock prices are effectively set by what the next buyer is willing to pay as reflected in the bidask spread. ${ }^{69}$ Third, this argument ignores some good reasons why companies might also want to keep stock prices low from time to time. For example, a company may plan to repurchase shares or to issue compensatory stock options. Or a company may want to discourage holders of convertible securities from exercising conversion rights. Finally, even though it seems unlikely that inflation fraud (so to speak) is a serious problem it turns out that diversification in practice addresses this possibility as discussed further below.

\section{DIVERSIFICATION IN PRACTICE}

The foregoing analysis has been based on a simplistic view of diversification: That investors can eliminate most of the risk that goes with investing in individual stocks (without any sacrifice of return) by holding a portfolio of twenty or more different stocks. But there is more to diversification. Intuitively, a portfolio of twenty different technology stocks or twenty different energy stocks would be over-exposed to industry-specific

67. See generally Lawrence A. Hamermesh \& Michael L. Wachter, The Short and Puzzling Life of the 'Implicit Minority Discount' in Delaware Appraisal Law, 156 U. PA. L. REV. 1, 4-7 (2007) (discussing Delaware case law with respect to minority discounts in appraisal proceedings); Richard A. Booth, Minority Discounts and Control Premiums in Appraisal Proceedings, 57 Bus. LAW. 127, 138-45 (2001) (discussing the application of minority discounts in appraisal proceedings under Delaware law).

68. See Charles R. Korsmo \& Minor Myers, Appraisal Arbitrage and the Future of Public Company M\&A, 92 WASH. U. L. Rev. 1551, 1598-1604 (2015) (discussing average appraisal awards).

69. See generally Richard A. Booth, The Efficient Market, Portfolio Theory and the Downward Sloping Demand Hypothesis, 68 N.Y.U. L. REV. 1187, 1203-07 (1993) (discussing share prices as a function of downward sloping demand theory). Similarly, Ibbotson suggests that the market imposes a liquidity discount. See 2015 IBBOtson StOcKs, Bonds, BILLS, AND INFLATION (SBBI) CLASSIC YEARBOOK 123 (2015) (estimating the cost of capital). 
risk: A stockholder who holds a portfolio of twenty stocks in a single industry remains exposed to the risks peculiar to that industry and thus assumes some risk that can be avoided with more diversification. So, diversification depends on the number and distribution of portfolio shares. But how do we know which stocks to include and in what proportions?

The market provides the answer. By holding (say) the 500 largest stocks in proportion to the market capitalization of each, an investor can be assured that invested funds are distributed according to an impartial assessment of business opportunities economy-wide. ${ }^{70}$ In effect, the market allocates capital to companies (and industries) through the pricing process. Presumably, companies invest where they find potential for return. ${ }^{71}$ So by holding the 500 or 1000 or 1500 largest stocks in proportion to the market capitalization of each portfolio company, one effectively allocates funds in proportion to returns available economy-wide. ${ }^{72}$

This explains the logic of investing in an index fund based on the valueweighted version of the S\&P 500 (SPX). ${ }^{73}$ Since size is directly proportional to returns, investing in an SPX index fund assures an investor that funds are distributed as broadly and evenly as possible across the entire array of business opportunities. ${ }^{74}$ The logic of doing so is more than mimicry for its own sake. $^{75}$

70. To be precise, the index holds stocks in proportion to public float rather than the total of outstanding common stock.

71. If $\mathrm{ABC}$ generates a $20 \%$ return while the rest of the market generates $10 \%$ return, the market will bid up the price of $\mathrm{ABC}$ until its return is consistent with the $10 \%$ average return from the rest of the market. Other things equal, $\mathrm{ABC}$ should double in value.

72. To be sure, it is conceivable that there are industries that are populated wholly by relatively small companies (or indeed private companies). For example, it seems unlikely that the index reflects the business of law or other professional practices. So, it is possible that a portfolio based on all publicly traded stocks is somewhat under-diversified in some ideal sense. But it is not clear that there is anything to be done about it.

73. SPX is the ticker symbol for the most widely followed version of the S\&P 500 - the version that measures price return only (without reinvestment of dividends).

74. The S\&P 500 represents about $80 \%$ of the value of the entire US market. In other words, the other 3000 or so US public companies account for just $20 \%$ or so of the total value of publicly held equity. To be clear, the S\&P 500 is composed solely of US stocks. One can diversify further (globally) by holding foreign stocks in addition to US stocks. Indeed, the US market accounts only for about $40 \%$ of world market. On the other hand, US companies presumably invest globally. So, international diversification is built in to some extent. Moreover, by limiting the index to US stocks, variations in governance, business norms, liquidity, market structure, and foreign exchange are neutralized, thus assuring apples-toapples comparison, which may also explain why so many widely followed indices are similarly limited to companies from a single country.

75. Indeed, one might argue that index investing is really quite aggressive in that it seeks to ferret out every possible source of return. 
In contrast, if one were to invest in an equal-weight portfolio - for example, the equal-weight version of the S\&P 500 (SPW) - one would effectively invest the same amount in the largest company therein (AAPL, which was worth $\$ 888 \mathrm{~B}$ as of year-end 2016) as in the smallest company therein (URBN, which is worth $\$ 2.46 \mathrm{~B}){ }^{76}$ While holding an equal-weight portfolio would avoid placing $3.9 \%$ of one's money in AAPL (or about $20 \%$ of one's money in the ten largest index companies), it would also mean that most of one's money was invested in the smallest index companies. ${ }^{77}$ Although smaller companies tend to generate higher returns, it is not clear what would be the rationale for investing in an equal-weight portfolio. Still, it turns out that the risk inherent in SPX is only slightly less than that inherent in SPW. ${ }^{78}$ In any event, an investor who picks stocks to hold in a diversified portfolio other than in proportion to market capitalization is not truly diversified - or, at least, not as diversified as she might be. In other words, to be truly diversified one must invest in a value-weighted portfolio.

The question is: Why would index investors trade at all (other than to add to or subtract from assets under management)? Given that trading entails some cost (if only in brokerage commissions), why not follow a strict buyand-hold strategy? The answer is that indexing compels some trading in order to maintain holdings in proportion to market capitalization. Stock prices rise and fall. So, every now and then the market portfolio must be rebalanced.

The practice with the S\&P 500 (the index itself) is to rebalance quarterly, while the leading SPX ETF (SPDRs) rebalances at least monthly. ${ }^{79}$

76. See PDR Services LLC, SPDR S\&P 500 ETF Trust Prospectus 33-37 (2017), http://quote.morningstar.com/fund-

filing/Prospectus/2017/1/19/t.aspx?t=SPY\&ft=\&d=c89aa2b84f2884869d37e2b7a32977d3

(listing the relative rankings); $S \& P 500$ Equal Weight Index, S\&P Dow JONES INDICES, http://us.spindices.com/indices/equity/sp-500-equal-weighted [https://perma.cc/9VWYRVUA] (last visited Nov. 30, 2017) (indexing values of company worth).

77. Incidentally, it turns out that one needs to invest in about 500 stocks in order both to hold a size weighted portfolio and to invest no more than about $4 \%$ by value in the largest stock therein. As noted above, most of the benefits of diversification can be achieved by holding twenty different stocks - which translates into investing no more than $5 \%$ in any one stock. Not so coincidentally, the Investment Company Act of 1940 includes a rule to the same effect - that for a fund to hold itself out as diversified it may not invest any more.

78. As of November 30, 2017, SPX had a ten-year STD of $15.08 \%$ while that of SPW was $17.76 \%$, both based on total returns. S\&P 500 Equal Weight Index, S\&P Dow JONES INDICES, http://us.spindices.com/indices/equity/sp-500-equal-weighted [https://perma.cc/9V WY-RVUA] (last visited Nov. 30, 2017).

79. See S\&P Dow Jones Indices, S\&P 500 FactsheEt (as of November 30, 2017) (Quick Facts / Rebalancing Frequency); SPDR S\&P 500 ETF TRUST, ProsPECTUS (January $19,2017)$ at 51-54. http://us.spindices.com/indices/equity/sp-500 and https://us.spdrs.com/ public/SPDR 500\%20TRUSTPROSPECTUS.pdf. 
But the trading prompted thereby is minimal. For the year 2016, turnover for SPX itself was $4.49 \%$ and was an even lower 4\% for SPDRs. ${ }^{80}$ In contrast, the average turnover rate for equity funds is $26 \%$ as of $2016 .{ }^{81}$ Assuming that roughly half of investor funds are indexed, and assuming a $26 \%$ average turnover rate for all funds, it must be that average turnover among managed funds is about $50 \%$ per year. ${ }^{82}$ Thus, index investors are almost always holders in the context of SFCAs. Translated into dollars, index investors stand to recover about $\$ 4$ for every $\$ 50$ recovered by other investors. More important, index investors effectively fund the difference. ${ }^{83}$

Quite aside from the fact that indexing entails very little trading, Spindler's critique (which assumes that diversified investors engage in a multitude of trades) ignores the fact that it is possible to trade portfolios as portfolios via exchange-traded index funds as well as options and futures. While it is likely that many individual stocks in the S\&P 500 (for example) are mispriced at any given moment, it is difficult to believe that the index is wrong. Indeed, it would be nonsense for an investor so to assert and irrational to act on any such belief. This is not to say that the S\&P 500 cannot rise or fall - or that an investor might predict that it will rise or fall. But that is quite different from saying that the index is mispriced. Moreover, even if there is reason to worry that the S\&P 500 is mispriced, there is no obvious way for an investor to take precautions against mispricing. Presumably, Spindler himself would agree that it would be foolish for an index investor to take any steps to guard against the possibility that other investors have better information about the S\&P 500. ${ }^{84}$ Moreover (and

80. See S\&P 500 AdDitional InFORMATION, CAPITAlization WEIGHTED TuRnOver (as of Nov., 30, 2017); SPDR S\&P 500 ETF TRUST, PROSPECTUS, (January 19, 2017) at 2.

81. See Investment Company Institute, 2017 InVESTMENT Company FACtBook, 38 (57th ed. 2017), available at https://www.ici.org/pdf/2017_factbook.pdf (noting that the longterm average turnover for the period 1984 to 2016 is $57 \%$ ).

82. See E-mail and attachment from Nicolas Stable, Manager, NYSE Reference Desk, ICE, to Richard A. Booth, Martin G. McGuinn Chair in Bus. Law, Villanova Univ. Charles Widger Sch. of Law (Nov. 15, 2018, 10:44 AM EST) (on file with author) (recording that the average turnover rate for NYSE group listed stocks has been $45 \%$ to $179 \%$ (monthly) during the period 2007 to September 2018). Note that turnover rate as reported both by ICI and NYSE has been dropping steadily over the last ten years, presumably because of investor movement into index funds (at least in part), although index ETFs themselves contribute significantly to NYSE Group turnover.

83. Needless to say, the outcome is even worse for buy-and-hold investors. On the other hand, buy-and-hold investors will not be members of a plaintiff class except when adding or subtracting funds to an investment account and thus may not have standing to object to class certification.

84. It quite possible to bet that the S\&P 500 will rise or fall in price by buying or selling index futures and other derivative instruments. But such speculation is different from taking precautions against mispricing. On the other hand, program trading (index arbitrage) may be 
again), we are concerned here only with company-specific information because SFCAs are filed against individual companies.

Nevertheless, someone must manage an index fund and do the trades that keep it in balance. If some of those trades happen at incorrect prices, the effects will flow through to the net asset value (NAV) of the fund.

It turns out that even if prices of individual stocks are skewed to the high side against buyers — which seems doubtful — portfolio-balance trading (PBT) effectively neutralizes any such bias. PBT requires the purchase of stocks that have risen in value (winners) and the sale of stocks that have declined in value (losers). By definition, an index fund must buy and sell portfolio securities in equal dollar amounts (ignoring inflows or outflows). In other words, PBT is a zero-sum game. So, assuming that upward bias in prices (if any) is uniformly distributed throughout the universe of stocks, any loss from such mispricing on purchases should be offset by a gain on sales. It all comes out in the wash.

Admittedly, PBT provides another reason why issuers (and their managers) may want to keep stock price high — to maximize demand from the large segment of the market that is indexed. Indeed, studies have shown that the addition of a stock to an index causes its price to rise a bit (and vice versa) ${ }^{85}$ Thus, indexing may give rise to a feedback effect of its own: Higher stock price means higher demand from index funds. And vice versa.

Note also that because PBT is based on the past performance of portfolio stocks (over as long as three months), index funds (and indeed the index itself) must lag the market in individual stocks. Accordingly, index investors effectively cede some gain to first-movers the active traders who collectively effect real change in the prices of individual stocks. On the other hand, ETFs (as well as program trading strategies) provide a second level of protection since the price of derivative instruments may vary from the index itself. If investors think the index is overpriced, they can bid down the price of the ETF accordingly. So, there is good reason to think that trading by index investors neutralizes much of any advantage that goes to active traders (and indeed may exploit its own mirror advantage).

The point (so far) has been that index investors do not in practice trade very much and that when they do trade, they trade in such a way as to

seen as a way to guard against mispricing. See Richard A. Booth, The Uncertain Case for Regulating Program Trading, 1994 Colum. Bus. L. REV. 1, 63 (noting that program trading may in the long run benefit specialists by implementing it when markets return to equilibrium).

85. See Jeffrey Wurgler, On the Economic Consequences of Index-Linked Investing (Nat'l Bureau of Econ. Res., Working Paper No. 16376, 2010) (arguing that index-linked investment has the effect of altering stock prices and risk evaluations relative to payoffs). 
neutralize any issuer efforts to keep stock prices inflated. It follows that index investors should be opposed to SFCAs insofar as they purport to compensate investors for ordinary losses coincident with fraud unavoidable losses from bad luck that someone must suffer. As for any portion of a loss that is attributable to fraud and thus avoidable, index investors would prefer recovery by the company by means of a derivative action. In other words, the point has been that investors that do diversify do not need (nor should they want) the protections afforded by SFCAs.

Quite aside from investor preferences, there are powerful arguments that investors should diversify and that the law should thus assume that ordinary investors are diversified (whether or not they are in fact diversified). In other words, we should encourage diversification as a matter of public policy. But SFCAs do just the opposite: They effectively subsidize (irrational) undiversified stock-picking investors at the expense of (rational) index investors. ${ }^{86}$

As shown at length above, an investor can avoid all company-specific risk without any sacrifice of expected return by holding a diversified portfolio of stocks. And one can do so at zero cost. (Although such a strategy entails some expense in the form of brokerage commissions, the same is true of stock-picking). Moreover, an investor can minimize such expenses by investing in an index fund. Management fees associated with index funds are significantly lower than those associated with actively managed mutual funds. The Investment Company Institute (ICI) reports that the average-expense ratio paid by investors in actively managed equity funds is $0.82 \%$ as of 2016 (which does not include sales loads — one time entry or exit fees - that average another $1.1 \%$ ). In contrast, the average-expense ratio for equity index funds is $0.09 \%$ annually. ${ }^{87}$ Indeed Schwab offers index funds with expenses of $0.03 \%$ and zero sales load. ${ }^{88}$ And Fidelity has just introduced a fund with zero management fees. Coincidentally (or not), studies show that on average managed funds underperform the market by about the amount of management fees and that the number of funds that beat

86. Many scholars, including Daniel Kahneman, Cass Sunstein, and Richard Thaler, have emphasized the importance of default rules that incline individuals to do the right thing. Daniel Kahneman, Thinking, Fast and Slow (2011); Richard H. Thaler \& Cass R. Sunstein, Nudge: Improving Decisions About Health, Wealth, and Happiness (2008). The argument against SFCAs is even stronger in that the choice is binary: Either the law provides a class action remedy or it does not.

87. INVESTMENT COMPANY INSTITUTE, supra note 81, at 38.

88. Charles Schwab, Schwab Equity Index Funds Prospectus, Schwab S\&P 500 Index Fund 1-3 (May 31, 2018), available at http://hosted.rightprospectus.com/SF/Fund.asp $\mathrm{x} ? \mathrm{cu}=808509855 \& \mathrm{dt}=\mathrm{P}[\mathrm{https}: / /$ perma.cc/B9QV-ZUBB]. For SPDRs, the expense ratio is $0.0945 \%$ per year. PDR SERVICES LLC, supra note 76, at 2. 
the market several years running is about the number one would expect based on chance. If I flip a coin enough times, it will occasionally come up heads several times in a row. But that does not mean I have skills. ${ }^{89}$

Third, given that diversified investors have hedged away all firmspecific risk, they are willing to pay more for the stocks in which they invest. In other words, diversified investors drive market prices: Since diversified investors assume less risk, they are willing to pay more for stocks. Accordingly, the growth of diversification (and indexing) has effectively bid up the price of equities generally. ${ }^{90}$ This also implies that investors who choose not to diversify effectively pay too much by assuming more risk than necessary for the same return. Thus, investors have no real choice but to diversify. $^{91}$

The bottom line is that it is irrational for most investors not to diversify. But to diversify is to render research a waste. Thus, it is also irrational to

89. See Burton G. Malkiel, A Random Walk Down Wall Street 177-84 (1996) (summarizing research that demonstrates how managed funds do not necessarily outperform the market due to this added level of management expertise). To be sure, an investor can avoid management fees altogether by constructing and maintaining a portfolio from scratch. But the expenses associated with a do-it-yourself portfolio are significant. Mutual funds pay about one cent per share in brokerage commissions when they trade whereas the $\$ 5$ or so per trade charged by the deepest discount brokers works out to five cents per share assuming a round lot of one hundred shares. To be sure, mutual funds may also suffer additional implicit costs because their trades affect market prices. But individuals may suffer similar costs because of high-frequency trading (HFT) practices. Note that fund-level brokerage commissions are not included in the expense ratios set forth above because commissions are deemed to be expenses borne by the fund itself and not part of the management fee charged by the adviser. But since index funds trade far less than actively managed funds, commission expenses can be assumed to be proportionally smaller for index funds. See generally Roger Edelen et al., Shedding Light on "Invisible" Costs: Trading Costs and Mutual Fund Performance, 69 FIN. ANALYSTS J. 33 (2013) (describing the various hidden costs of fund trading and their effect on investor returns).

90. Over the period 1930 through 2016, increasing P/E ratios have accounted for $0.62 \%$ in price return. See Richard A. Booth, Appraisal Rights and Economic Growth 11 (Dec. 5, 2017) (unpublished manuscript), (available at https://ssrn.com/abstract=3082862 [https://perma.cc/VG6C-MYCM]) (noting "that $0.62 \%$ of price return is attributable to a general increase in the value of equities as measured by the forward price/earnings ratio"). It seems quite likely that this element of growth has been the result of increasing diversification as well as declines in commissions and other expenses of investing. See Richard A. Booth, Five Decades of Corporation Law, 53 VILL. L. REV. 459, 466 (2008) (stating that in the 1980s "as brokerage commissions fell, it became almost costless to assemble a diversified portfolio.”).

91. By analogy to Gresham 's Law ("bad money drives out good money"), one might say that diversified investors drive stock-pickers from the market since stock-pickers are forced to pay prices that are determined as if there is no firm-specific risk. Call it Booth's Law. In other words, stock-pickers assume additional risk without the prospect of any additional return. 
spend anything more than the minimum possible amount on investment management.

To be clear, this logic does not necessarily apply to investors who seek to influence the business strategies of individual firms. Think Warren Buffett. For such investors, expected returns derive from active participation in management. For them, it is no contradiction to expect return to exceed expected return (so to speak). But activist investors (hedge funds, private equity funds, and other investors who seek to influence the management strategies of target businesses) must pay the premium prices that are effectively set by diversified investors. ${ }^{92}$

To be sure, it could be argued that such investors (who are rationally undiversified) need the protection offered by SFCAs. Moreover, it seems quite unlikely that legal remedies make much difference to the trading activity of such investors. But given that such investors tend to invest relatively large amounts, they often will have an adequate incentive to sue if defrauded. They do not need a class action remedy. ${ }^{93}$ Indeed, it has become increasingly common for such investors to opt out of SFCAs in favor of pursuing individual recovery, which is problematic in itself. ${ }^{94}$

\section{TRANSFORMING Class ACTIONS INTO DERIVATIVE ACTIONS}

The point of this essay (to this point) has been to respond to the arguments of James Spindler as to why the widely accepted academic critique of SFCAs should be rejected. In other words, the point has been to

92. Since such investors typically must also pay a premium over market price in order to gain control whatever the level, it follows that they must perceive significant room for improvement. This should be somewhat reassuring to those who suspect that such investors are focused on short-term returns or otherwise seek to promote policies that are inconsistent with the interests of stockholders and the broader economy.

93. Nor do they need the benefit of the FOTM presumption of reliance even though the courts have held that the presumption applies even in the context of an individual action. See GAMCO Inv'rs, Inc. v. Vivendi Universal, S.A., 838 F.3d 214, 217-18 (2d Cir. 2016) (demonstrating the willingness of an investment company to bring an individual securities fraud action separate from a class action lawsuit).

94. See Amir Rozen et al., Opt-Out Cases in Securities Class Action Settlements 20122014 Update, CORnERSTONE RESEARCH 1, 6 (2016), https://www.cornerstone.com/Publicatio ns/Reports/Opt-Out-Cases-in-Securities-Class-Action-Settlements-2012-2014 (finding "over 50 percent of class actions with settlements above $\$ 500$ million (and 75 percent of such cases in 2012 to 2014) had opt-outs."). This trend is disturbing in that it may permit large investors to appropriate funds available for recovery to the exclusion of small investors and without the protections afforded in the context of a class action - which is not to mention the bigger point argued here that recovery should go to the company. See Smith v. Waste Mgmt., Inc., 407 F.3d 381, 386 (5th Cir. 2005) (holding that plaintiff's individual claims were barred by res judicata due to prior settlement against defendant on behalf of all stockholders). 
explain why the arguments against SFCAs are indeed valid — albeit with some tweaking. Nevertheless, as noted more than once up to now, Spindler is correct that some sort of remedy for fraud is necessary if only for purposes of deterrence. But no one has seriously suggested otherwise. The problem is that no one has proposed a compelling alternative (present company excluded).

As I have argued here and elsewhere, derivative actions solve all of the problems that beset SFCAs and provide tailored deterrence and compensation that is perfectly proportional to the genuine (undiversifiable) harm suffered by investors. There is no feedback because the company recovers. And because the company recovers only to the extent that it suffers harm as a company, a derivative action affords recovery only for the portion of a loss that cannot be diversified away.

The obvious objection to supplanting SFCAs with derivative actions is that individual defendants are likely to be largely judgment proof — unlikely to have the personal wealth necessary to fund a settlement that makes much difference. There are several responses.

First, the potential damages award in a derivative action is likely to be quite small in comparison to that in a class action wherein the measure of damages includes not only the harm to company but also diversifiable losses and feedback (notwithstanding the fact that the loss is limited to that suffered by buyers).

Second, SFCA settlements are typically funded wholly by D\&O insurance. ${ }^{95}$ Although it has been argued that D\&O insurance will not cover claims by a company against its own directors, officers, and agents, there appear to be significant exceptions to this pattern. ${ }^{96}$ Moreover, there is no doubt that insurers would provide such insurance if there was demand for it. Witness the invention of earnings insurance a few years back. ${ }^{97}$ And since companies already pay for coverage against SFCAs the same funds could be

95. Kevin LaCroix, D\&O Insurance to Fund Entire "Largest Ever" \$139 Million News Corp. Derivative Suit Settlement, THE D\&O DIARY (Apr. 23, 2013), https://www.dandodiary.com/2013/04/articles/shareholders-derivative-litigation/doinsurance-to-fund-entire-largest-ever-139-million-news-corp-derivative-suit-settlement/ [hereinafter D\&O Insurance to Fund "Largest Ever" Derivative Suit]; Kevin LaCroix, About the AIG Derivative Settlement, THE D\&O DiARY (Sept. 11, 2008), https://www.dandodiary .com/2008/09/articles/shareholders-derivative-litigation/about-the-aig-derivative-settlement/ [hereinafter About the AIG Derivative Settlement].

96. D\&O Insurance to Fund "Largest Ever" Derivative Suit, supra note 95; About the AIG Derivative Settlement, supra note 95.

97. See Richard A. Booth, Reducing Risk Doesn't Pay Off, Wall St. J., Mar. 15, 1999, at A18 (describing earnings-protection insurance as a new way for companies to protect themselves from the effects of unexpected low earnings). 
diverted to coverage against derivative actions. To be sure, such insurance would be for the benefit of high-level officers and thus might be seen as a form of compensation. ${ }^{98}$ But so be it. In the end, the company is no worse off.

It may suffice simply to describe the advantages of derivative actions without suggesting how such a change might be implemented. But it is relatively easy to get from here to there.

First, the character of an action (whether it is derivative or direct) is a matter for the court to determine. ${ }^{99}$ So the courts could simply declare that SFCAs should be litigated as derivative actions.

Second, the conflicting interests of diversified investors, who should disfavor class certification for the reasons laid out above, as well as the impracticability of defining a class of investors who would favor class certification should preclude class certification under Rule 23(b)(3). It is simply impossible for anyone to be an adequate class representative where half of the class would be opposed to the position advocated. ${ }^{100}$

Third, Rule 23(b)(3) requires that a direct class action for money damages be superior to other means of resolving the dispute. Since a derivative action is perfectly tailored to the task, the superiority requirement cannot be satisfied (at least if a litigant argues for a derivative action or the court determines to act on its on motion). ${ }^{101}$

98. Cf. Frank H. Easterbrook \& Daniel R. Fischel, Optimal Damages in Securities Cases, 52 U. CHI. L. REv. 611, 640 (1985) (noting that individual liability would lead directors, officers, and other agents to demand more compensation).

99. See Tooley v. Donaldson, Lufkin, \& Jenrette, Inc., 845 A.2d 1031, 1039 (Del. 2004) (outlining the test for the court to use to determine whether the action is a derivative or direct claim). See also LaSala v. Bordier et Cie, 519 F.3d 121, 126-27 (3d Cir. 2008) (demonstrating a derivative claim brought by shareholders); Smith v. Waste Mgmt, Inc., 407 F.3d 381, 385 (5th Cir. 2005) (holding that plaintiff's claims were derivative under Delaware law); Cowin v. Bresler, 239 U.S. App. D.C. 188, 741 F.2d 410, 414 (D.C. Cir. 1984) (holding that appellant's common law claims must be brought on a derivative basis); Shirvanian v. DeFrates, 161 S.W.3d 102, 110 (Tex. App. 2004) (finding that shareholders' claims were derivative under Delaware law). $C f$. Bangor Punta Operations, Inc. v. Bangor \& Aroostook R. Co., 417 U.S. 703, 715-18 (1974) (holding that since the plaintiff does not meet the contemporaneous ownership requirement, he has no standing to pursue a derivative action).

100. See Hansberry v. Lee, 311 U.S. 32, 44-45 (1940) (holding that a class action is inappropriate where some members of the class are opposed to the position taken by the representative plaintiff). Moreover, there is no apparent way to define the class so as to segregate class members who would oppose the action from those who would favor the action. Cf. Comcast Corp. v. Behrend, 569 U.S. 27 (2013) (finding that class certification was improper where plaintiff could not show that damages could be awarded on a class-wide basis).

101. In addition, Fed. R. Civ. P. 23(b)(3) also requires the court to consider: "(B) the extent and nature of any litigation concerning the controversy already begun by or against class 
One potential difficulty is that the plaintiff corporation in a derivative action is unlikely to be a purchaser or seller and thus will not have standing to sue under Rule 10b-5 because of the Blue Chip Stamps doctrine. ${ }^{102}$ In the end, this is not a problem because the action may proceed in state court, and state law clearly recognizes such claims. ${ }^{103}$ Although the Securities Litigation Uniform Standards Act (SLUSA) of 1998 sought generally to preempt securities litigation in state court, the so-called Delaware carve-out expressly permits derivative actions. Thus, one could argue that Congress has impliedly endorsed the solution proposed here (although it seems quite unlikely that it did so consciously). ${ }^{104}$

members," and "(C) the desirability or undesirability of concentrating the litigation of the claims in the particular forum." Interestingly, Fed. R. Civ. P. 23.1, which governs derivative actions, was part of Rule 23, which governs class actions, until 1966 when the two were divided into separate sections. Thus, one could argue that the issue whether a claim should be handled as a class action or derivative action is essentially one of management by the court (which is also a factor to be considered under Rule 23) as where the court must decide what type of class action is most appropriate. See, e.g., Wal-Mart Stores, Inc. v. Dukes, 564 U.S. 338, 361 (2011) (ruling that employment discrimination actions must proceed under Rule 23(b)(3) rather than Rule 23(b)(2)).

102. Blue Chip Stamps v. Manor Drug Stores, 421 U.S. 723, 754-56 (1975). See, e.g., Schoenbaum v. Firstbrook, 405 F.2d 215, 219 (2d Cir. 1968), (discussing a derivative action in which the purchaser-seller requirement was met). It may also be a problem that the corporation's cause of action is not one sounding in deception. See Santa Fe Industries, Inc. v. Green, 430 U.S. 462- 63 (1977) (finding that corporate mismanagement does not fall under rule $10 b-5)$.

103. See, e.g., Malone v. Brincat, 722 A.2d 5 (Del. 1998) (holding that the complaint adequately stated claim for breach of duty of loyalty based on insider trading); Pfeiffer v. Toll, 989 A.2d 683 (Del. Ch. 2010) (explaining the distinction between a derivative claim based on financial harm to the corporation as a result of securities fraud and insider trading by directors and a claim for damages or disgorgement based on stockholder losses). See also Kahn v. Kolberg Kravis Roberts \& Co., 23 A.3d 831, 837 (Del. 2011) (abrogating Pfeiffer to hold that a corporation could not recover for insider trading gains); Brenner v. Albrecht, No. 6514VCP, 2012 Del. Ch. LeXIS 20, at *19-23 (granting the motion to stay the state law derivative action until the resolution of the federal securities fraud class action).

104. It is not clear that the Blue Chip Stamps doctrine should apply in the context of a derivative action. Since the doctrine is judicially crafted, the courts have the power to make exceptions where appropriate. See Merrill Lynch, Pierce, Fenner \& Smith, Inc. v. Dabit, 547 U.S. 71, 86 (2006) (construing SLUSA connection requirement independently of judicially imposed Blue Chip Stamps standing requirement). For example, it may suffice that a corporation has suffered harm in the form of an excess decline in market price because traders have reacted to managerial misbehavior. Although the foregoing argument as to why the federal courts might hold that a derivative cause of action may arise under Rule 10b-5 may seem to be a stretch, Exchange Act $\S 16(\mathrm{~b})$ expressly contemplates derivative recovery by the corporation in connection with short-swing trading by insiders. Moreover, the danger at which the doctrine was aimed - litigation over trading that might or might not have happened in the absence of misinformation - is not a problem where the harm to the corporation is measurable and finite. 
Moreover, it should not matter whether the action arises under federal or state law as long as it provides appropriate deterrence. And there is good reason to think that a claim will lie under state law in any situation in which a meritorious claim will lie under federal law (as discussed further below).

One likely argument against supplanting SFCAs with derivative actions is that derivative actions are subject to a variety of procedural hurdles such as the requirement of demand on the board of directors (BOD). Moreover, a derivative action can be voluntarily dismissed on motion by the BOD or a special litigation committee (SLC) thereof. Finally, most corporations have adopted charter provisions that exculpate directors (and officers) from liability to the corporation for mismanagement. ${ }^{105}$

Needless to say, SFCAs are themselves subject to a variety of procedural hurdles as well. And often the litigation over such matters ends up being dispositive. So, it is not clear that the peculiar rules relating to derivative actions would be a more significant impediment for plaintiffs. If anything, the ever evolving rules relating to class actions seem to be more complex.

As for the possibility of voluntary dismissal by BOD or SLC motion or under an exculpatory charter provision, the rule has evolved that where the individual wrongdoers (directors or officers or other agents of the corporation) have acted with scienter, demand will be excused and an exculpatory charter provisions will not apply because of the requirement of good faith. ${ }^{106}$

105. In addition, recent scholarship has suggested that derivative actions tend to reduce stockholder wealth. See Adam B. Badawi \& Daniel L. Chen, The Shareholder Wealth Effects of Delaware Litigation, 19 AM. L. \& ECON. REV 287, 287-326 (2017) (summarizing scholarship that demonstrates that derivative actions can reduce shareholder wealth). But as noted therein, this may owe to the fact that most derivative actions are settled for nonmonetary governance reforms or disclosure, which itself may owe (in part) to the inherent inconsistency between recovery from the corporation (in SFCAs) and recovery by the corporation (as would be normal in a derivative action). And that is not to mention the oftennoted point that insurance may not cover derivative settlements (for a variety of reasons). In other words, we do not know how the market would react to the prospect of derivative actions supplanting SFCAs. It is conceivable that the prospect of recovery by the corporation would have the effect of muting the effects of events that currently result in significant price declines not only because feedback is eliminated but also because the market anticipates that the corporation will recover from the wrongdoers.

106. See In re The Goldman Sachs Group, Inc. S'holder Litig., No. 5215-VCG, 2011 Del Ch. LeXIS 151, at *42 (Del. Ch. Oct. 12, 2011) (holding that "failure to act in good faith requires conduct that is qualitatively different from, and more culpable than, the conduct giving rise to a violation of the fiduciary duty of care (i.e., gross negligence)."); In re Walt Disney Co. Derivative Litig., 907 A.2d 693, 755 (Del. Ch. 2005) (concluding that there was no gross negligence and thus no breach of a fiduciary duty of care). See also Stone v. Ritter, 911 A.2d 362, 369 (Del. 2006) (adopting a good faith standard for a breach of a fiduciary duty 
While it might be argued that scienter may mean something different in the context of a state law fiduciary duty claim than what it means in the context of a claim arising under Rule 10b-5, fiduciary duty as interpreted by the Delaware courts incorporates a duty of candor that would appear to make any misrepresentation that is actionable under federal law also actionable under state law assuming a showing of harm to the corporation (which is just as it should be). ${ }^{107}$

Moreover, one distinct advantage of litigating securities fraud in the context of a derivative action is to dispense with the scienter requirement as applied under Rule 10b-5 where its function is to distinguish between actionable misrepresentation and merely negligent misrepresentation. As demonstrated at length here, the proper measure of recovery in a derivative action is the loss in excess of what would be expected from corrective disclosure alone. The problem with direct - class - recovery under Rule 10b-5 is that it depends on a judgment call as to the culpability of the speaker. The fit is less than perfect. Scienter is not congruent with merit. And it is inevitable that the courts will sometimes get it wrong. In contrast, the focus in a derivative action is on whether the corporation suffered any measurable harm (or the individual defendants were unjustly enriched). No harm. No foul. And no need to delve into the mental state of the actors. In other words, the market can provide the answer. If corrective disclosure results in no greater change in stock price than would be expected from the new information disclosed - if no additional harm is done - there is no need for recovery. To be sure, it is not necessarily a simple matter to determine whether a corporation has suffered excess loss. But it seems preferable to try rather than to rely on the extant measure of damages that over-

of care).

107. See In re infoUSA, Inc. S'holders Litig., 953 A.2d 963, 990 (Del. Ch. 2007) (finding that directors violate their fiduciary duty where it can be shown that they issued communication with the knowledge that it was deceptive or incomplete, because stockholders are entitled to honest communications from directors given with complete candor and in good faith even in the absence of a request for stockholder action); Malone v. Brincat, 722 A.2d 5, 16 (Del. 1998) (holding that a stockholder plaintiff can demonstrate a BFD by showing that the directors "deliberately misinform[ed] stockholders about the business of the corporation either directly or by a public statement."). See also Pfeiffer v. Toll, 989 A.2d 683, 708 (Del. Ch. 2010) (holding that a stockholder may maintain a derivative action against directors and officers for losses suffered by the company as a result of federal securities law claims against corporation by buyers). Indeed, since the law of fiduciary duty reaches a wide range of misbehavior beyond misrepresentation, state law provides a more comprehensive remedial scheme than federal securities law. To be sure, not all corporations are incorporated in Delaware. But it seems likely that the courts of other states will look to Delaware law in this area because of the expertise of the Delaware courts derived from the large number of such cases litigated there in courts that specialize in such matters. 
compensates buyers and over-deters managers. ${ }^{108}$

Admittedly, a derivative action does nothing to compensate sellers in good-news cases: If good news is covered up and stock price rises with corrective disclosure, those who sold at a too-low price during the fraud period gain nothing from recovery by the corporation. But good-news cases are quite rare, because feedback in such cases operates to dampen any increase in price and thus to reduce the damages that the plaintiff class might recover (whereas feedback has the opposite effect in bad news cases), or possibly because companies tend to be eager to disclose good news. In any event, my own research indicates that fewer than one in fifty SFCAs is a good-news case. Thus, it is ironic that many of the most notable judicial decisions relating to SFCAs have involved aggrieved sellers in good-news situations. $^{109}$ One solution to this problem might be to permit SFCAs in good-news cases - in effect to require defendant companies to disgorge the gains captured for the benefit of buyers and holders. Note that in a goodnews context, a class action would undo the effects of feedback and would afford the correct level of deterrence. ${ }^{110}$ Thus, consistent with the arguments for a derivative remedy in the context of bad-news cases, one argument for permitting SFCAs in the context of good-news cases is that a derivative action is an inferior remedy. ${ }^{111}$

108. In contrast, there is no reason to presume scienter from the fact of loss under Rule $10 \mathrm{~b}-5$ because the measure of damages includes ordinary diversifiable losses that are going to happen one way or the other. Admittedly, the approach to scienter suggested here largely dispenses with any need to litigate the matter. Rather, scienter is effectively presumed where there is excess loss. See Easterbrook \& Fischel, supra note 14, at 644 (noting that the scienter requirement may operate to calibrate the excesses of a loss-based measure of damages).

109. See, e.g., Basic Inc. v. Levinson, 485 U.S. 224 (1988) (demonstrating an influential case brought by aggrieved sellers that accused the corporation of material misrepresentation); Santa Fe Indus., Inc. v. Green, 430 U.S. 462 (1977) (ruling against the aggrieved sellers' complaint that accused the corporation of wrongly completing a short-form merger); Blue Chip Stamps v. Manor Drug Stores, 421 U.S. 723 (1975) (holding that Congress did not intend to extend a private cause of action for loss of the opportunity to purchase due to an overly pessimistic prospectus); Affiliated Ute Citizens v. United States, 406 U.S. 128 (1972) (awarding damages to the aggrieved sellers); SEC v. Texas Gulf Sulphur Co., 401 F.2d 833 (2d Cir. 1968) (demonstrating a case brought by the SEC on behalf of aggrieved sellers after the defendants traded on inside information not available to the public).

110. At the risk of sounding a bit gee-whiz, it is really quite amazing how the law works (almost as a living thing) to provide solutions even to the most convoluted problems.

111. See Perlman v. Feldmann, 219 F.2d 173, 178 (2d Cir. 1955) (awarding damages to minority stockholders in a derivative action claim did not fully reimburse their losses). Perlman is akin to a 1933 Act remedy in reverse. Id. 


\section{CONCLUSION}

In We Have a Consensus on Fraud on the Market - And It's Wrong, James Spindler has attempted to defend securities fraud class actions (SFCAs) and the fraud-on-the-market (FOTM) doctrine by purporting to refute two arguments that have been cited by numerous scholars: (1) the circularity (feedback) critique and (2) the diversification critique. In essence, Spindler's gist is that SFCAs are both workable and necessary. But in the end, Spindler fails to accomplish his goal. Quite to the contrary, he succeeds in exposing weaknesses in the usual arguments against SFCAs that ultimately point the way to still stronger arguments against SFCAs.

Regarding circularity, Spindler argues that SFCAs are workable because it is possible even with circularity for investors to be compensated in full even though compensation is funded by a reduction in the aggregate value of the defendant company and thus the wealth of its stockholders (including those who are compensated). Spindler recognizes that circularity gives rise to feedback and thus (where the class comprises buyers) causes stock price to fall further than it otherwise would do. But he fails to recognize that because feedback magnifies buyer claims, it induces investors to spend that much more on precaution and increases already excessive deterrence. Moreover, and more important, it effects a transfer of wealth from diversified investors to stock-picking investors even though the law should encourage investors to diversify.

Regarding diversification, Spindler argues that SFCAs are necessary because one cannot diversify away fraud. But as shown here, the loss from securities fraud is a mixture of diversifiable losses that someone will suffer one way or the other (when the truth comes out) and undiversifiable losses that derive from the cover-up of bad news. Bad things happen to good companies. Sales decline. Risks increase. But such losses can be diversified away because unexpectedly good things happen to other companies. In contrast, if an ordinary loss is exacerbated by a cover-up leading to a loss of investor trust (and an increased cost of capital) or cash outflows (from litigation expenses or fines), such additional losses cannot be offset by unexpected gains. There is no potential for gain from the absence of fraud.

The only losses that really matter are the losses that cannot be diversified away. But these are losses suffered by the corporation that should give rise to a derivative action. If we sort out the sources of loss suffered by investors in SFCAs, it turns out that derivative actions are perfectly tailored to afford a remedy for the true harm addressed in SFCAs while providing perfectly calibrated deterrence without the collateral damage caused by feedback. 